\title{
Corticotropin-Releasing Factor Receptors in the Rat Central Nervous System: Characterization and Regional Distribution
}

\author{
Errol B. De Souza \\ Neuroscience Branch, Addiction Research Center, National Institute on Drug Abuse, Baltimore, Maryland 21224
}

\begin{abstract}
A stable, iodine-125-labeled analog of rat/human corticotropin-releasing factor (CRF) was used to define the characteristics of CRF receptors in a crude mitochondrial/synaptosomal membrane preparation of rat olfactory bulb, and to study the distribution of CRF binding sites in discrete regions of the rat CNS. The binding of ${ }^{225 \mid}$-Tyr ${ }^{\text {rat/human CRF }}$ ( ${ }^{125}$-rCRF) was time- and temperature-dependent, was sensitive to the $\mathrm{pH}$, ionic strength, and cationic composition of the incubation buffer, and was linear over a broad range of membrane protein concentrations. ${ }^{125}$-rCRF binding to olfactory bulb membrane was saturable, reversible, and, on Scatchard analysis, revealed a high-affinity component with an apparent equilibrium dissociation constant $\left(K_{d}\right)$ of $0.2 \mathrm{nM}$ and a low-affinity binding site with $K_{\mathrm{d}}$ of approximately 20 nM. Data from pharmacological studies indicated that the ability of a variety of CRF fragments and analogs to inhibit 125|-rCRF to olfactory bulb membranes correlates well with their reported relative potencies in stimulating pituitary adrenocorticotropic hormone secretion in vitro. Consistent with a coupling of CRF receptors to adenylate cyclase, the binding of ${ }^{125} \mid-r C R F$ was decreased by guanine nucleotides and increased by magnesium ions. A heterogeneous distribution of ${ }^{25}$ I-rCRF binding sites was found in the rat CNS, with highest densities present in olfactory bulb, cerebellum, cerebral cortex and striatum, and progressively lower but significant levels of binding were detected in cervical spinal cord, hypothalamus, medulla, midbrain, thalamus, pons, and hippocampus. These data, using a rat CRF ligand homologous to the endogenous peptide, are consistent with those from previous studies demonstrating the presence of specific binding sites for ovine CRF in rat brain, and provide further support for the suggestion that endogenous CRF may function as a neurotransmitter in the CNS.
\end{abstract}

\footnotetext{
Received Feb. 18, 1986; revised July 14, 1986; accepted July 22, 1986

I would like to thank Dr. Michael J. Kuhar for the use of his laboratory facilities and for his helpful comments concerning the experimental design and the manuscript. I thank R. Proctor for technical assistance and S. Krout and M. Flutka for manuscript preparation. I am especially grateful to Jean Rivier of the Salk Institute Peptide Biology Laboratory for providing CRF analogs and fragments, to Martin Ewer and Russell Garlick of New England Nuclear for generously supplying ${ }^{125}$ ITyr ${ }^{0}$-rat/human CRF, to George Battaglia for helpful discussions, and to Ronald Emeson for help in HPLC characterization of CRF solutions and tissue extracts. This work was supported in part by NIMH Grant MH25951, and by a grant from the McKnight Foundation.

Correspondence should be addressed to Errol B. De Souza, Ph.D., Neuroscience Branch, Addiction Research Center, National Institute on Drug Abuse, P.O. Box 5180, Baltimorc, MD 21224.

$0270-6474 / 87 / 010088-13 \$ 02.00 / 0$
}

Corticotropin-releasing factor (CRF), a 41-amino-acid peptide originally isolated from ovine hypothalami (Vale et al., 1981), stimulates the release of proopiomelanocortin (POMC)-derived peptides from the anterior and intermediate lobes of the pituitary gland (reviewed in Vale et al., 1983; De Souza, 1985). More recently, the amino acid sequences of both rat (Rivier et al., 1983) and human (Shibihara et al., 1983) CRF have been elucidated and were found to be identical to one another, but to differ from ovine CRF by 7 amino acid residues. In addition to its endocrine role at the pituitary, CRF has been demonstrated to have a broad extrahypothalamic distribution in the CNS (Olschowka et al., 1982; Cummings et al., 1983; Swanson et al., 1983), and to produce a wide spectrum of autonomic (Brown et al., 1982; Fisher et al., 1983; Tache et al., 1983) and behavioral (Britton et al., 1982; Morley and Levine, 1982; Sutton et al., 1982; Sirinathsinghji et al., 1983; Veldhuis and De Wied, 1984) effects. The results of these studies have led to the suggestion that CRF may act as a neurotransmitter or neuromodulator in the CNS, where it appears to play a role in the integration of the organism's responses to stress. A neurotransmitter role for CRF in the rat CNS is further supported by several findings at the cellular level, including its release from brain slices in a calcium-dependent manner following potassium stimulation (Smith et al., 1986), the ability of CRF to alter neuronal firing rates following iontophoretic application (Aldenhoff et al., 1983; Eberly et al., 1983; Valentino et al., 1983), and its ability to promote the formation of cAMP (Wynn et al., 1984; Chen and Bilezikjian, 1985). Recently, we and others have reported the autoradiographic identification and characterization of specific binding sites for iodine-125-labeled analogs of ovine CRF in rat (De Souza et al., 1984b, 1985a, b; Wynn et al., 1984; De Souza and Kuhar, 1986a, b), monkey (De Souza and Kuhar, 1986a, b) and human (De Souza and Kuhar, 1986b) brain; however, specific binding sites for endogenous $\mathrm{CRF}$ remain to be identified and characterized in rat brain. In the present study, we have used a stable, iodine-125-labeled analog of the endogenous ligand ${ }^{125} \mathrm{I}-\mathrm{Tyr}^{0}{ }^{\mathrm{rat}} / \mathrm{human} \mathrm{CRF}\left({ }^{125} \mathrm{I}-\mathrm{rCRF}\right)$ to examine in detail the kinetic and pharmacological characteristics and regional distribution of $\mathrm{CRF}$ receptors in rat brain membrane homogenates.

\section{Materials and Methods}

Animals. Male Sprague-Dawley rats (Madison, WI) weighing 175-250 gm were used throughout this study. Animals were housed in a lightand temperature-controlled room, with food and water available ad libitum.

Materials. Iodinated rat CRF (specific activity, $2200 \mathrm{Ci} / \mathrm{mmol}$ ) was obtained from New England Nuclear (Boston, MA); unlabeled rat and ovine CRF were purchased from Peninsula Laboratories (Belmont, CA). 


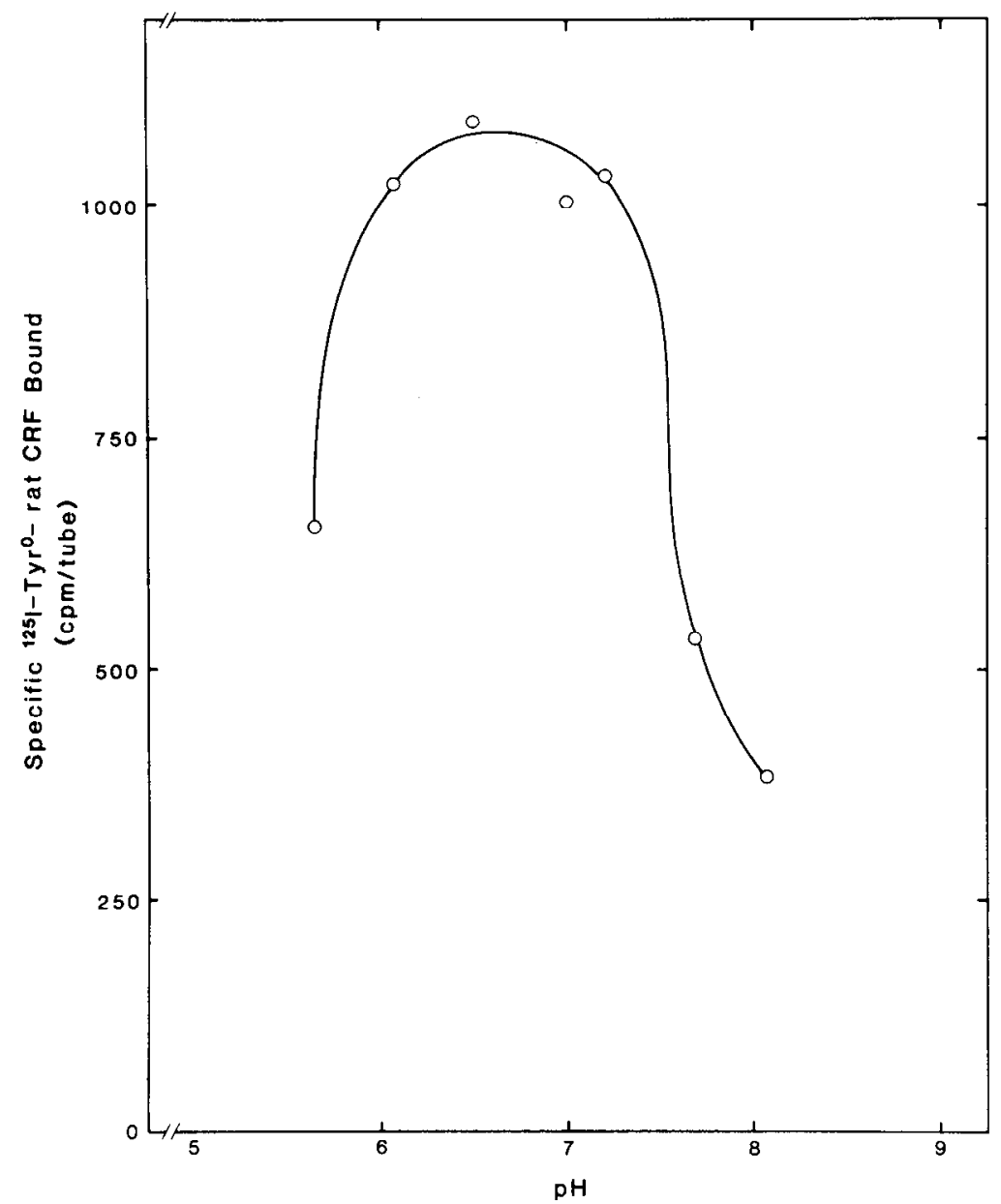

Figure 1. Effect of $\mathrm{pH}$ on ${ }^{125} \mathrm{I}-\mathrm{Tyr}^{0} \mathrm{rat} /$ human CRF binding to rat olfactory bulb membranes. ${ }^{125} \mathrm{I}-\mathrm{Tyr}^{0} \mathrm{rat} / \mathrm{human}$ CRF was incubated in $50 \mathrm{~mm}$ Tris- $\mathrm{HCl}$, $10 \mathrm{~mm} \mathrm{MgCl}_{2}, 2$ mm EGTA, $10^{4} \mathrm{M}$ bacitracin, and 100 kallikrein units $/ \mathrm{ml}$ aprotinin for $120 \mathrm{~min}$ at room temperature with a crude mitochondrial/synaptosomal membrane preparation at $\mathrm{pH}$ values ranging from 5.5 to 8.2 . Each point is the average of 3 or 4 determinations, which differed by less than $10 \%$.

All of the CRF fragments, analogs, and vasoactive intestinal peptide, arginine vasopressin, angiotension $\mathrm{II}$, and $\mathrm{His}^{1}, \mathrm{Nle}^{27}$ growth hormonereleasing factor $(1-32) \mathrm{NH}_{2}$ used in displacement experiments were synthesized and generously provided by Dr. Jean Rivier of the Salk Institute Peptide Biology Laboratory (La Jolla, CA). All other standard reagents were purchased from Sigma (St. Louis, MO); guanosine 5 'triphosphate (GTP) and 5'-guanylimidodiphosphate (GppNHp) were used as the sodium salts.

Tissue preparation. Rats were killed by decapitation, and brain regions of interest were dissected as previously described (Glowinski and Iversen, 1966), weighed, and placed in 30 volumes of ice-cold buffer (50 mM Tris- $\mathrm{HCl}, 10 \mathrm{~mm} \mathrm{MgCl}_{2}, 2 \mathrm{~mm}$ EGTA, and $0.32 \mathrm{M}$ sucrose; $\mathrm{pH}$ 7.2). All assays were run using freshly dissected tissue, except for assays of anterior pituitary tissue; anterior pituitaries were collected on dry ice and stored at $-70^{\circ} \mathrm{C}$ until assayed. The tissue was homogenized by 10 passes of a Teflon pestle homogenizer. In routine studies, the homogenate was centrifuged at $4^{\circ} \mathrm{C}$ for $10 \mathrm{~min}$ at $1000 \times \mathrm{g}$, the resulting pellet $\left(P_{1}\right)$ was discarded and the supernatant $\left(S_{1}\right)$ was recentrifuged at $4^{\circ} \mathrm{C}$ for $30 \mathrm{~min}$ at $20,000 \times \mathrm{g}$. The resulting supernatant $\left(\mathrm{S}_{2}\right)$ was discarded and the pellet $\left(\mathrm{P}_{2}\right)$ was saved. Subcellular fractionation studies were carried out as previously described (Whittaker and Barker, 1972); the $P_{1}$ pellet was saved and the supernatant $\left(S_{2}\right)$ from the second centrifugation was recentrifuged at $4^{\circ} \mathrm{C}$ for $60 \mathrm{~min}$ at $100,000 \times g$; the supernatant $\left(\mathrm{S}_{3}\right)$ was discarded and the pellet $\left(\mathrm{P}_{3}\right)$ was saved. All pellets were resuspended in $50 \mathrm{~mm}$ Tris- $\mathrm{HCl}, 10 \mathrm{~mm} \mathrm{MgCl}_{2}, 2 \mathrm{~mm}$ EGTA, $0.1 \% \mathrm{BSA}$, aprotinin

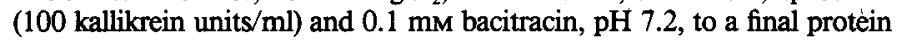
concentration of $0.25-0.5 \mathrm{mg} / \mathrm{ml}$, using a Brinkman polytron (Westbury, NY) set at 5 for $20 \mathrm{sec}$. Final protein concentration of each membrane preparation was determined by the method of Lowry et al. (1951) using BSA as a standard.

${ }_{125} I-r C R F$ binding assay. One hundred microliters of the membrane suspension was added to $1.5 \mathrm{ml}$ polypropylene microtubes (Sarstedt, W. Germany) containing $100 \mu \mathrm{l}$ of an ${ }^{125}$ I-rCRF solution (approximately $30,000 \mathrm{cpm}$ ) and $100 \mu \mathrm{l}$ of the incubation buffer or an appropriate concentration of unlabeled rat/human CRF (rCRF) or other competing peptide. Nonspecific binding was determined in the presence of $1 \mu \mathrm{M}$ rCRF. The reaction was allowed to proceed for $2 \mathrm{hr}$ at room temperature. The tissue was separated from the incubation medium by centrifugation in a Beckman microfuge for $3 \mathrm{~min}$ at $12,000 \times \mathrm{g}$. The resulting pellet was washed gently with $1 \mathrm{ml}$ of ice-cold PBS, $\mathrm{pH} 7.2$, containing $0.01 \%$ Triton $\mathrm{X}$, and the contents were recentrifuged for $3 \mathrm{~min}$ at $12,000 \times$ $g$. The supernatant was aspirated and the radioactivity of the pellet was measured in a gamma counter at $80 \%$ efficiency.

$R P-H P L C$ analysis of CRF solutions and tissue extracts. Aliquots of an ${ }^{125}$ I-rCRF solution (approximately $3000 \mathrm{cpm}$ ), the supernatant from the first centrifugation of a sample assayed as described above, and an acid extract ( $20 \%$ acetonitrile in $0.1 \%$ trifluoroacetic acid) from the final pellet of the same sample were analyzed by reversed-phase high-performance liquid chromatography (RP-HPLC) on a Waters $\mathrm{C}_{18} \mu$-Bondapak column $(4.6 \mathrm{~mm} \times 30 \mathrm{~cm})$ equilibrated with solution A $(20 \%$ acetonitrile in $0.1 \%$ trifluoroacetic acid) at a flow rate of $1.0 \mathrm{ml} / \mathrm{min}$; 10 min after sample injection, a linear gradient to $85 \%$ solution B $(80 \%$ acetonitrile in $0.1 \%$ trifluoroacetic acid) over $65 \mathrm{~min}$ was initiated. Unlabeled rCRF was detected by absorbance at $220 \mathrm{~nm}$.

Data analysis. The ${ }^{125}$ I-rCRF binding data were analyzed by the computer program EBDA (McPherson, 1983), which provides initial estimates of equlibrium binding parameters by Scatchard, Hill, and EadieHofstee analysis and then produces a file for the nonlinear curve-fitting program LIGAND (Munson and Rodbard, 1980), which gives final parameter estimates.

\section{Results}

Preliminary studies to optimize and characterize ${ }^{125}$ I-rCRF in olfactory bulb membranes

On the basis of previous autoradiographic localization studies of the distribution of binding sites for an iodine-125-labeled 
Figure 2. Effect of ionic strength of Tris-HCl buffer on ${ }^{125} \mathrm{I}-\mathrm{Tyr}^{\circ} \mathrm{rat} /$ human CRF binding to rat olfactory bulb membranes. ${ }^{125}$ I- $\mathrm{Tyr}^{\circ}$ rat/human CRF was incubated for $120 \mathrm{~min}$ at room temperature in $25-170 \mathrm{~mm}$ Tris- $\mathrm{HCl}$ buffer, $\mathrm{pH} 7.2$, containing $10 \mathrm{mM} \mathrm{MgCl}_{2}$, $2 \mathrm{mM}$ EGTA, $10^{-4} \mathrm{M}$ bacitracin, and 100 kallikrein units $/ \mathrm{ml}$ aprotinin with a crude mitochondrial/synaptosomal membrane preparation. Each point is the average of 3 or 4 determinations, which varied by less than $10 \%$.

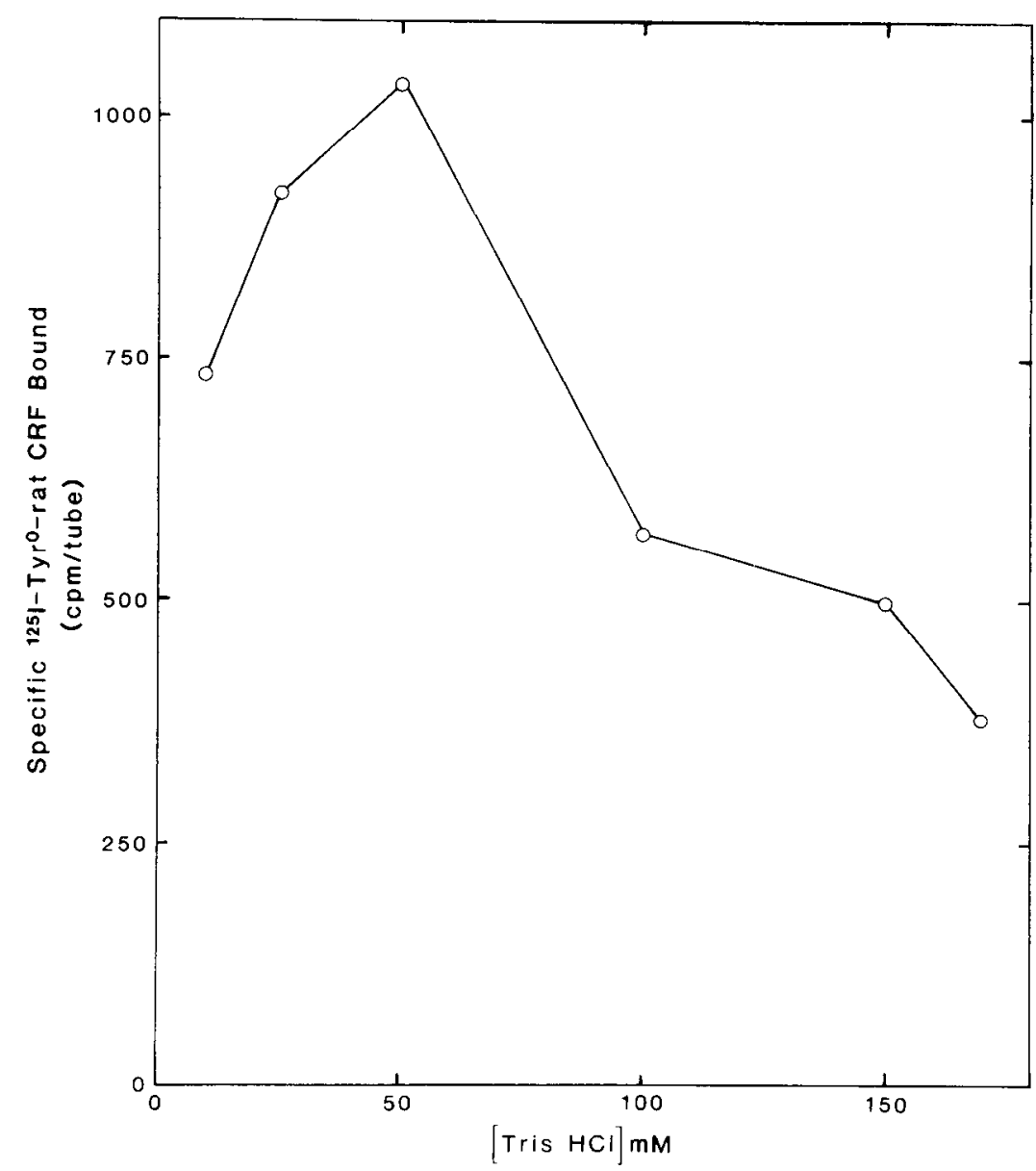

in the nonspecifically bound ${ }^{125}$ I-rCRF. Tissue that was boiled for $5 \mathrm{~min}$ before incubation showed no detectable specific ${ }^{125} \mathrm{I}-$ rCRF binding. On the basis of these preliminary experiments, all subsequent assays were routinely performed in $50 \mathrm{~mm}$ Tris$\mathrm{HCl}$ buffer containing $10 \mathrm{mM} \mathrm{MgCl}_{2}\left(\mathrm{pH} 7.2\right.$ at $23^{\circ} \mathrm{C}$ ), and the incubations were carried out with a membrane protein concentration of $25-50 \mu \mathrm{g} / \mathrm{tube}$. In addition, the protease inhibitors bacitracin $\left(10^{-4} \mathrm{M}\right)$ and aprotinin (100 kallikrein units $\left./ \mathrm{ml}\right)$ were included in the incubation buffer to minimize degradation of the peptide and/or receptor during the course of the assay. Under these assay conditions, specific binding represented $70-75 \%$ of total ${ }^{125}$ I-rCRF binding.

To determine whether the assay conditions described above were effective in limiting degradation of ${ }^{125} \mathrm{I}-\mathrm{rCRF}$, and to ascertain that membrane-bound radioactivity represented intact ${ }^{125}$ I-rCRF, analytical RP-HPLC profiles of the added ligand, the postincubation supernatant, and extracted membrane-bound ligand were compared. After 120 min of incubation, the ${ }^{125}$ I-rCRF in the incubation medium and ${ }^{125}$ I-rCRF extracted from the membrane pellet eluted as a single peak with fresh ${ }^{125}$ I-rCRF (Fig. 5), thereby demonstrating the stability of the radioiodinated ligand under routine assay conditions, as well as confirming the identity of the membrane-bound ${ }^{125}$ I-rCRF.

The subcellular distribution of ${ }^{125}$ I-rCRF binding sites was examined by comparing binding levels observed in pellets obtained from successive fractionation steps. The total number and density of specific ${ }^{125}$ I-rCRF binding sites were greater in the crude mitochondrial/synaptosomal pellet $\left(P_{2}\right)$ than in the $P_{1}$ protein concentration to approximately 100 . higher protein concentrations resulted primarily in an increase 


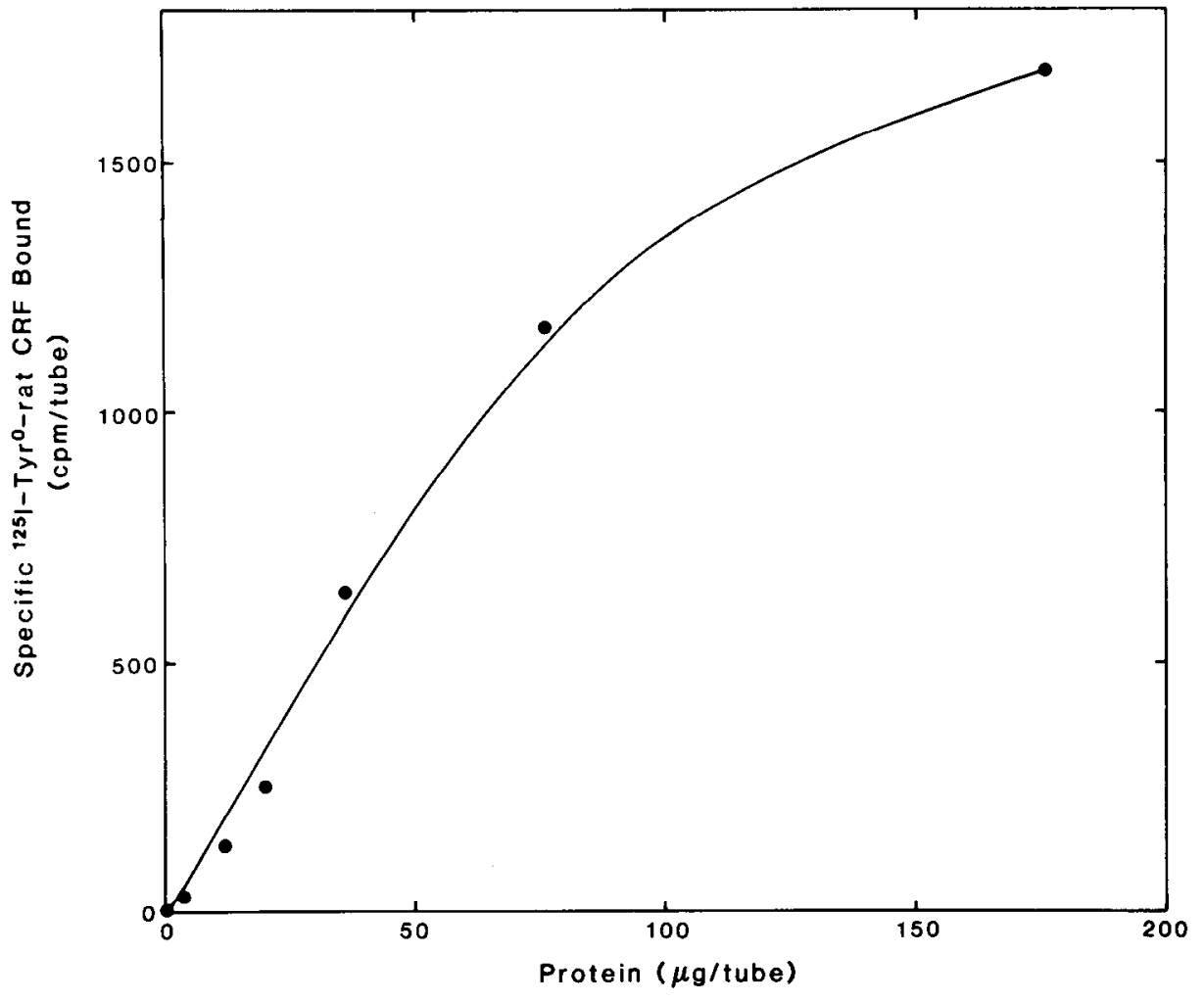

Figure 3. ${ }^{125} \mathrm{I}-\mathrm{Tyr}^{0}$ rat/human CRF binding to rat olfactory bulb as a function of the membrane protcin concentration. ${ }^{125} \mathrm{I}-\mathrm{Tyr}^{0} \mathrm{rat} / \mathrm{human} \mathrm{CRF}$ was incubated for $120 \mathrm{~min}$ at room temperature in standard incubation buffer with increasing concentrations of crude mitochondrial/synaptosomal membranes. Each point is the average of 4 determinations, which varied by less than $10 \%$. fraction representing nuclei and cellular debris (Table 1). No significant ${ }^{125} \mathrm{I}-\mathrm{rCRF}$ binding was found in the microsomal pellet $\left(P_{3}\right)$. This crude subcellular distribution of binding sites for ${ }^{125} I-$ rCRF is consistent with a localization of binding to membranes derived from nerve terminals.

\section{Kinetics of ${ }^{125}$ I-rCRF binding to receptors}

The time courses of ${ }^{125} \mathrm{I}$-rCRF association to rat olfactory bulb membranes are shown in Figure 6. The association rate of ${ }^{125}$ IrCRF was temperature-dependent and exhibited pseudo-firstorder kinetics. At room temperature $\left(23^{\circ} \mathrm{C}\right)$, the binding increased with time to reach a steady state after $90 \mathrm{~min}$ and equilibrium binding conditions persisted till at least $3 \mathrm{hr}$ of incubation. The rate of association was more rapid at $37^{\circ} \mathrm{C}\left(K_{1}=\right.$ $\left.1.9 \times 10^{9} \mathrm{M}^{-1} \mathrm{~min}^{-1}\right)$ than at room temperature $\left(K_{1}=5.2 \times 10^{8}\right.$ $\mathrm{M}^{-1} \mathrm{~min}^{-1}$ ) but this increased rate of association at $37^{\circ} \mathrm{C}$ was accompanied by a substantially lower level and duration of equilibrium-specific binding of ${ }^{125} \mathrm{I}-\mathrm{rCRF}$. The decrease in ${ }^{125} \mathrm{I}-$ rCRF binding with longer periods of incubation at $37^{\circ} \mathrm{C}$ probably resulted from a more rapid degradation of the ligand, as evidenced by the proportionally higher level of nonspecific binding at this temperature (data not shown). Negligible amounts of specific ${ }^{125} \mathrm{I}-\mathrm{rCRF}$ binding were observed at $4^{\circ} \mathrm{C}$, with incubation periods lasting up to $2 \mathrm{hr}$.

The time course of ${ }^{125}$ I-rCRF dissociation from rat olfactory bulb membranes is shown in Figure 7. ${ }^{125}$ I-rCRF binding decreased as a function of time following the addition of $1 \mu \mathrm{M}$ unlabeled rat $\mathrm{CRF}$, demonstrating the reversibility of the binding reaction. A plot of $\ln \left(B / B_{\mathrm{m}}\right)$ against time (see inset in Fig. 7) resulted in a monophasic profile at both 23 and $37^{\circ} \mathrm{C}$. The rate of dissociation of ${ }^{125}$ I-rCRF was temperature-dependent, with more rapid dissociation observed at $37^{\circ} \mathrm{C}\left(\mathrm{K}_{-1}=0.32\right.$ $\left.\min ^{-1}\right)$ than at $23^{\circ} \mathrm{C}\left(\mathrm{K}_{-1}=0.007 \mathrm{~min}^{-1}\right)$, corresponding to apparent half-times of 2.2 and $99 \mathrm{~min}$, respectively.

\section{${ }^{125} I-r C R F$ binding characteristics at equilibrium}

The concentration-dependent equilibrium binding of ${ }^{125}$ I-rCRF to rat olfactory bulb membranes was examined and is shown in Figure 8A. Specific ${ }^{125}$ I-rCRF binding was saturable and Scatchard analysis of the saturation data (Fig. $8 B$ ) indicates that the binding is of high affinity, with an apparent equilibrium dissociation constant $\left(K_{\mathrm{d}}\right)$ of $192 \mathrm{pm}$ and a maximum number of binding sites $\left(B_{\max }\right)$ of $243 \mathrm{fmol} / \mathrm{mg}$ protein.

In the range of ligand concentrations $(0.05-1 \mathrm{nM})$ used in our saturation studies, ${ }^{125}$ I-rCRF appears to bind to a single class of sites, as indicated by both the straight line obtained from the

Table 1. ${ }^{125 I-T y r^{0}}$ rat/human CRF binding to subcellular fractions of rat olfactory bulb

\begin{aligned} Olfactory bulb fraction & $\begin{array}{l}\text { Specific }{ }^{125} \text { I-Tyr }{ }^{0} \text { rat/ } \\ \text { human CRF bound } \\ (\mathrm{fmol} / \mathrm{mg} \text { protein) }\end{array} \\$\hline $1000 \times g$ pellet $\left(\mathrm{P}_{1}\right) & 17.1 \pm 0.2 \\ 20,000 \times g$ pellet $\left(\mathrm{P}_{2}\right) & 31.0 \pm 1.0 \\ 100,000 \times g$ pellet $\left(\mathrm{P}_{3}\right) & 0\end{aligned}$

Crude fractions of rat olfactory bulb were prepared as described in Materials and Methods. Aliquots of tissue comprising the various fractions were incubated with $35 \mathrm{pM}^{125} \mathrm{I}-\mathrm{Tyr}^{0} \mathrm{rat} / \mathrm{human} \mathrm{CRF}$ for $120 \mathrm{~min}$ at room temperature in the absence (total) or presence (blank) of $1 \mu \mathrm{M}$ unlabeled rat CRF. At the concentration of ligand used in the fractionation studies, approximately $15 \%$ of the total ${ }^{125} \mathrm{I}-\mathrm{Ty} \mathrm{r}^{\circ}$ rat/human CRF binding sites were occupied. The data are based on 5 determinations from a representative experiment (mean \pm SEM), which were confirmed by 2 independent repetitions of the experiment and were found to vary less than $10 \%$ from each other. 
Figure 4. Effects of cations on ${ }^{123} \mathbf{I}-\mathrm{Tyr}^{\mathrm{0}}$ rat/human CRF binding to rat olfactory bulb membranes. ${ }^{125}$ I-Tyr ${ }^{0} \mathrm{rat} /$ human CRF was incubated for $120 \mathrm{~min}$ at room temperature in $50 \mathrm{~mm}$ Tris- $\mathrm{HCl}$ containing $2 \mathrm{~mm}$ EGTA, $10^{-4} \mathrm{M}$ bacitracin, 100 kallikrein units $/ \mathrm{ml}$ aprotinin, $\mathrm{pH}$ 7.2 , and varying concentrations of $\mathrm{MgCl}_{2}$ (triangles), $\mathrm{CaCl}_{2}$ (squares), and $\mathrm{NaCl}$ (circles). Each point is the average by less than $10 \%$. of 3 or 4 determinations, which varied

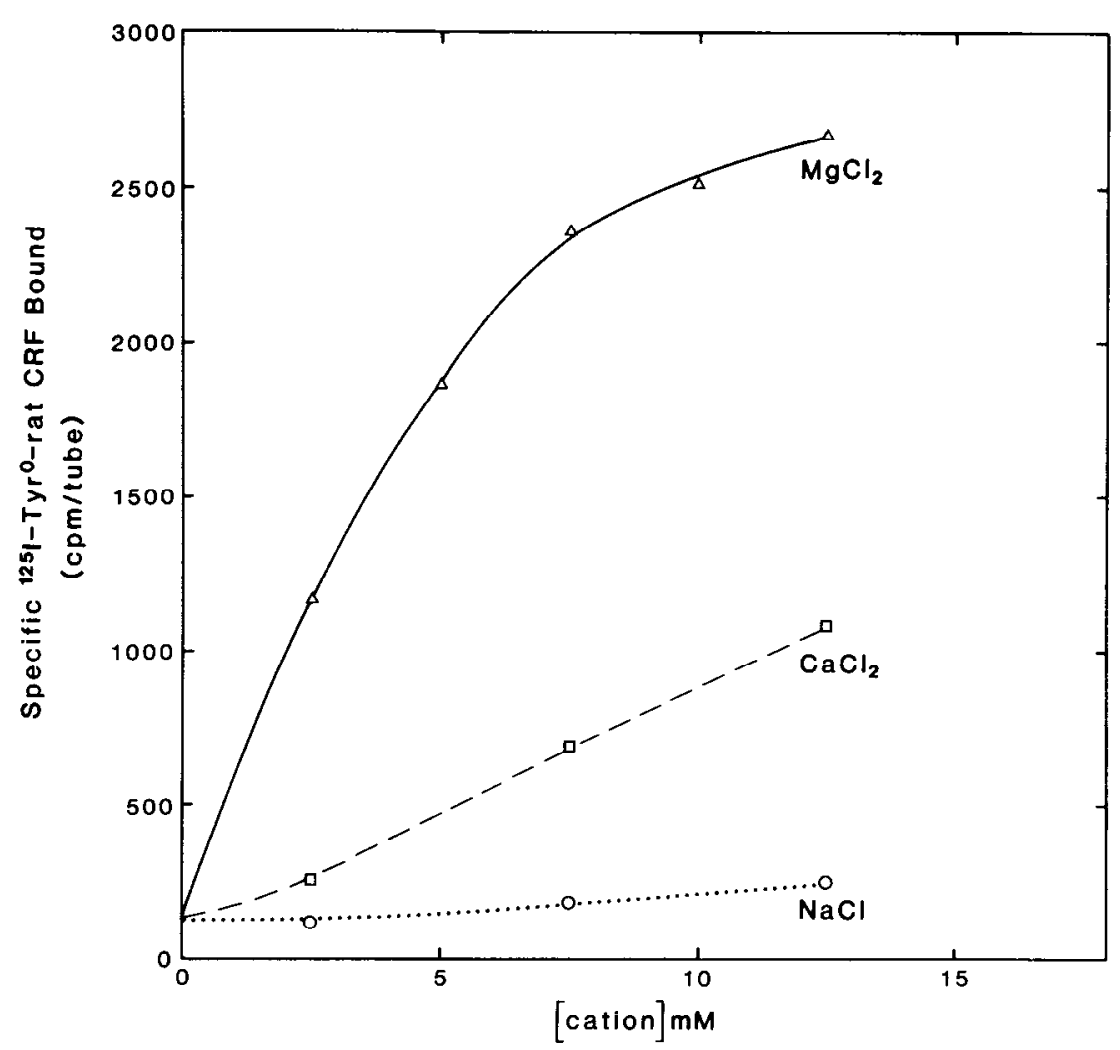

Scatchard plot (correlation coefficient $=0.98$ ) and a Hill coefficient of 1.0 (correlation coefficient $=0.99$ ). Displacement studies employing increasing concentrations of unlabeled rCRF $(0.1-$ $100 \mathrm{nM}$ ) yielded a curvilinear plot of bound hormone versus bound/free hormone. Analysis of these Scatchard data using the nonlinear curve-fitting program LIGAND (Munson and Rodbard, 1980) suggests the presence of a second, lower-affinity CRF binding site with an apparent $K_{\mathrm{d}}$ of approximately $20 \mathrm{nM}$; the Hill coefficient associated with binding under these conditions was 0.75 (data not shown).

Pharmacological characteristics of the binding site were examined by determining the relative potencies of a variety of CRF-related and unrelated peptides in displacing specifically bound ${ }^{125}$ I-rCRF. The results of these studies are summarized in Figure 9 and Table 2. Rat CRF was slightly more potent than the ovine analog in displacing the iodinated ligand; the inhibitory binding-affinity constant $\left(K_{\mathrm{i}}\right)$ values for rat and ovine CRF were 1 and $2.5 \mathrm{nM}$, respectively. Acetylated ovine CRF (4-41), a fragment more potent than the endogenous ligand in stimulating ACTH release, exhibited a slightly higher affinity $\left(K_{\mathrm{i}}=\right.$ $0.5 \mathrm{nM}$ ) for the ${ }^{125} \mathrm{I}-\mathrm{rCRF}$ binding site, whereas ovine CRF (139), a fragment with 1000-fold lower potency in the ACTH bioassay, was approximately 1000 times less potent than the endogenous ligand in displacing ${ }^{125} \mathrm{I}-\mathrm{rCRF}$ from its binding site. The putative weak CRF antagonist, alpha-helical CRF (9-41), displaced the ${ }^{125}$ I-rCRF with a $K_{\mathrm{i}}$ value of approximately $15 \mathrm{nM}$. A variety of biologically inactive CRF fragments representing the amino terminus [rCRF (1-20)], the carboxy terminus [rCRF (21-41)], and the middle portion [rCRF (6-33)] of the active pcptide were found to have no effect on ${ }^{125}$ I-rCRF binding. Equally ineffective in displacing ${ }^{125} \mathrm{I}-\mathrm{rCRF}$ binding were the unrelated peptides angiotensin II, arginine vasopressin, vasoactive intestinal peptide, and an analog of growth hormone-releasing factor. There is an excellent correlation between the reported relative potencies of the CRF-related peptides in stimulating ACTH secretion in vitro and their potency in inhibiting ${ }^{125} \mathrm{I}$ rCRF binding in brain (Table 2).

\section{Effects of nucleotides and magnesium on ${ }^{125}$ I-rCRF binding}

Guanine nucleotides have been shown in a number of receptor cyclase-coupled systems to selectively decrease the affinity of agonists for their receptors. By contrast, magnesium ions are thought to enhance agonist binding to adenylate cyclase-coupled receptors by stabilizing the high-affinity form of the receptoreffector complex. To determine whether CRF receptors in brain might be coupled to adenylate cyclase, we carried out a series of studies to examine the effects of magnesium ions and nucleotides on ${ }^{125} \mathrm{I}-\mathrm{rCRF}$ binding in rat olfactory bulb. The addition of increasing concentrations of GTP to the incubation medium resulted in an inhibition of ${ }^{125}$ I-rCRF binding; the nonhydrolyzable GTP analog GppNHp was even more potent (Fig. 10). This effect appeared to be specific to the guanine nucleotides, as similar experiments indicated that equimolar concentrations of ATP had no effect on ${ }^{125}$ I-rCRF binding (data not shown). GTP and GppNHp inhibited a maximum of 50\% of the specific ${ }^{125}$ I-rCRF binding. Conversely, as mentioned previously, magnesium ions appeared to be obligatory for obtaining significant ${ }^{125}$ I-rCRF binding in olfactory bulb; specific ${ }^{125}$ I-rCRF binding increased in a linear fashion with increasing concentrations of $\mathrm{MgCl}_{2}$ (Fig. 3). To determine whether the effects of guanine nucleotides and magnesium ions were mediated by changes in receptor density or affinity, we carried out a series of parallel ${ }^{125} \mathrm{I}-\mathrm{rCRF}$-saturation assays in the presence of 1 and $10 \mathrm{mM} \mathrm{MgCl}_{2}$ and $200 \mu \mathrm{M} \mathrm{NaGTP}$. The Scatchard analysis of these saturation data is presented in Figure 11. GTP increased the apparent $K_{\mathrm{d}}$ of ${ }^{125} \mathrm{I}-\mathrm{rCRF}$ by $35 \%$; this decrease in affinity 


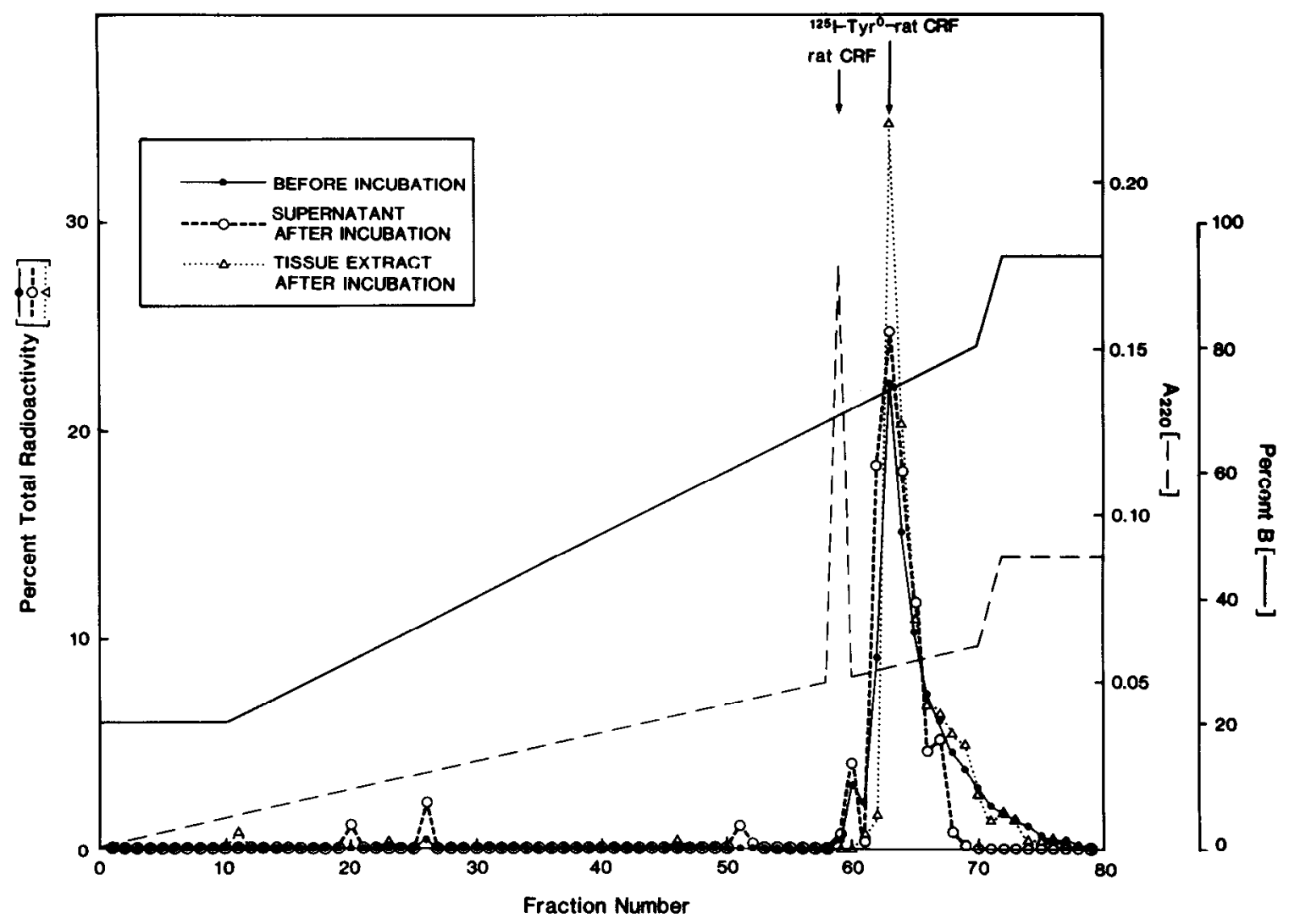

Figure 5. RP-HPLC profile of ${ }^{25}{ }^{25}-\mathrm{Tyr}^{0} \mathrm{rat} /$ human CRF: Effects of incubation with rat olfactory bulb membranes. Crude mitochondrial/synaptosomal membranes were incubated under standard assay conditions with ${ }^{125} \mathrm{I}-\mathrm{Tyr}^{0} \mathrm{rat} / \mathrm{human} \mathrm{CRF}$ for $120 \mathrm{~min}$ at room temperature. The reaction was terminated by centrifugation at $12,000 \times g$ for $3 \mathrm{~min}$. Aliquots of ${ }^{12} \mathrm{~T}$-Tyr ${ }^{\circ}$ rat/human CRF in the medium before and after, and a $20 \%$ acetonitrile in $0.1 \%$ trifluoroacetic acid extract of the tissue-bound radioactivity were analyzed by RP-HPLC using conditions described in Materials and Methods. The elution profile of unlabeled rat $C R F$ was determined by absorbance at $220 \mathrm{~nm}$. For symbols, see inset.

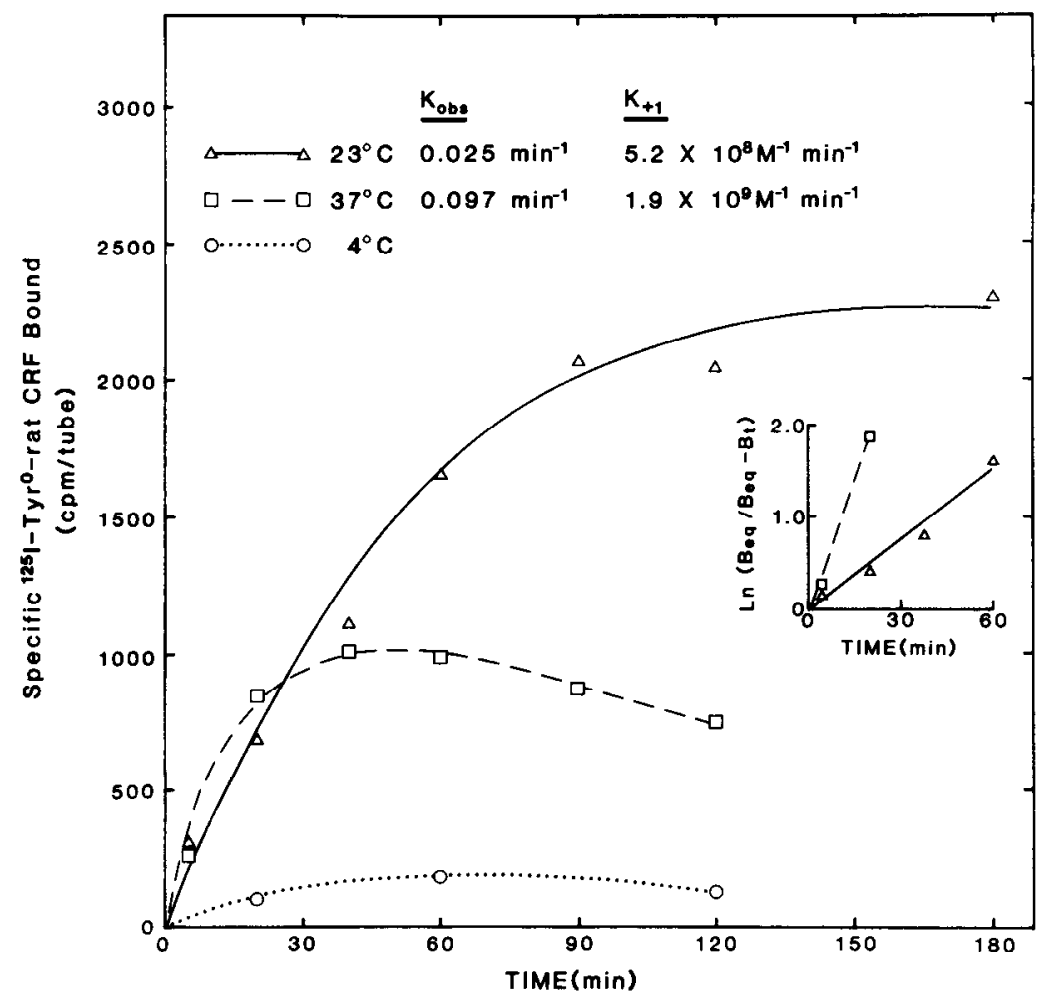

Figure 6. Time course association of ${ }^{125} \mathrm{I}-\mathrm{Tyr}^{0} \mathrm{rat}^{\mathrm{h}}$ human CRF to rat olfactory bulb membranes as a function of temperature. Specific binding of ${ }^{125} I-$ $\mathrm{Tyr}^{\circ} \mathrm{rat} / \mathrm{human} \mathrm{CRF}$ at $4^{\circ} \mathrm{C}, 23^{\circ} \mathrm{C}$, and $37^{\circ} \mathrm{C}$ is plotted as a function of time after tissue addition. Nonspecific binding (binding in the presence of $1 \mu \mathrm{M}$ rat CRF) was subtracted from total binding. Linear conversion of the association data is included as an inset, where $B e q$ represents specific binding at the steady-state level and $B_{\mathrm{t}}$ represents specific binding at time $t$. Linear regression yielded the slope presented as $K_{u(x, y}$ which was used in the calculation of the association rate constant, $K_{+}$. Each val$u e$ is the average of 3 or 4 determinations, which varied by less than $10 \%$. 
Figure 7. Time course of dissociation of ${ }^{125}$ I-Tyr ${ }^{0} \mathrm{rat} / \mathrm{human}$ CRF from rat olfactory bulb membranes as a function of temperature. Binding of ${ }^{125} \mathrm{I}-\mathrm{rCRF}$ at $23^{\circ} \mathrm{C}$ and $37^{\circ} \mathrm{C}$ as a function of time after the addition of excess unlabeled peptide. Homogenates were incubated with ${ }^{125} \mathrm{I}-\mathrm{Tyr}^{0} \mathrm{rat} / \mathrm{human} \mathrm{CRF}$ at room temperature for $120 \mathrm{~min}$ and dissociation was initiated by the addition of 1 $\mu \mathrm{M}$ rat CRF. Linear conversion of the data is included as an inset, where $B$ represents binding at time $t$ and $B_{\mathrm{m}}$ represents maximal binding; linear regression yielded the slope indicated as $K_{-1}$. Each value is the average of 3 or $4 \mathrm{de}$ terminations, which varied by less than $10 \%$.

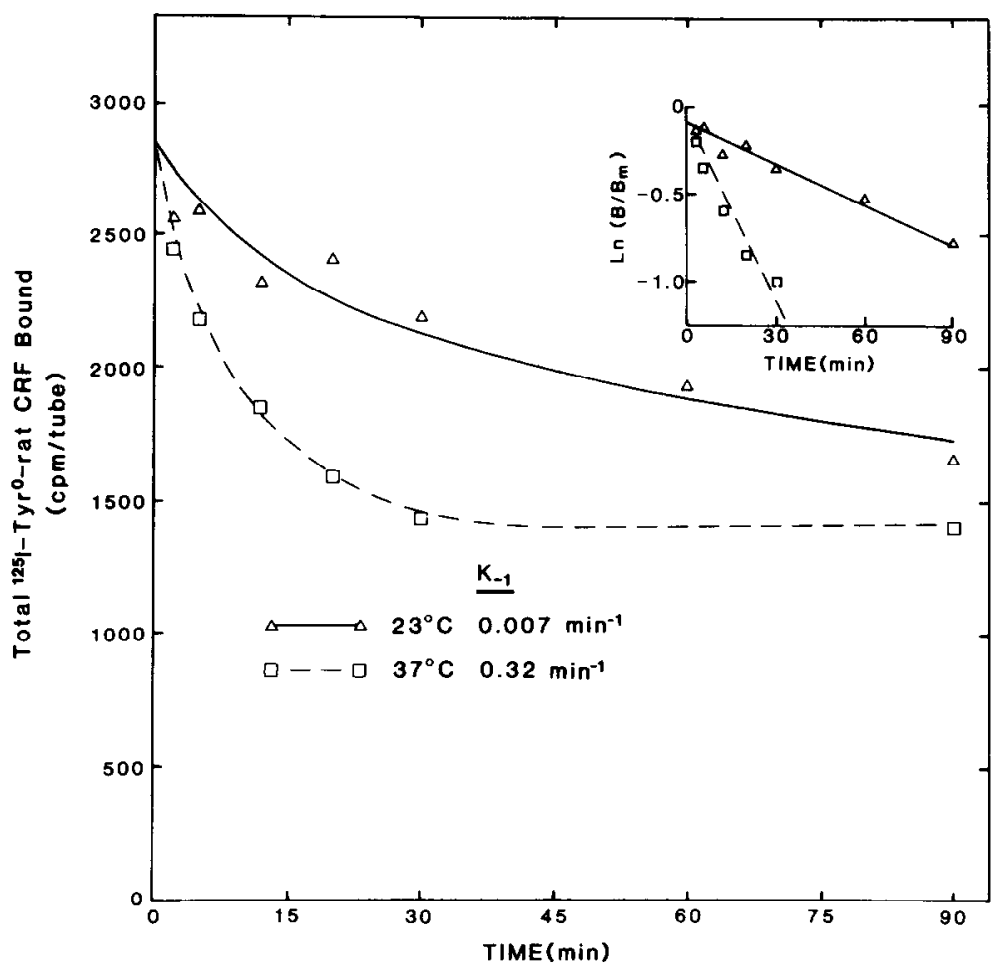

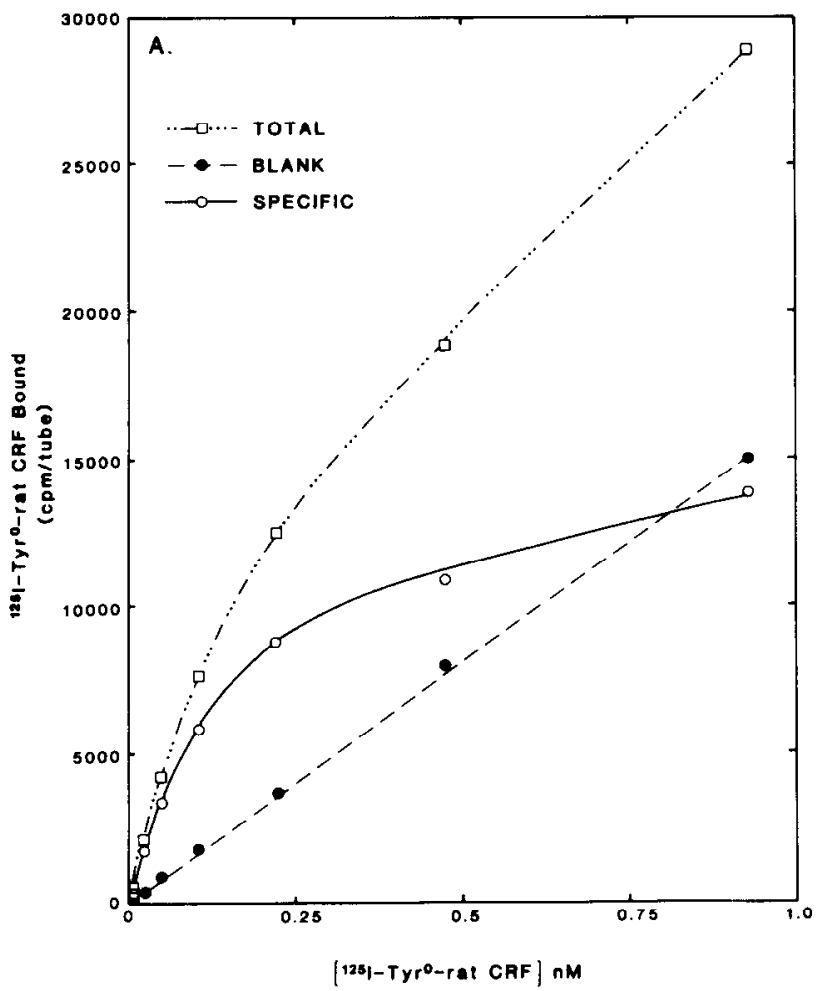

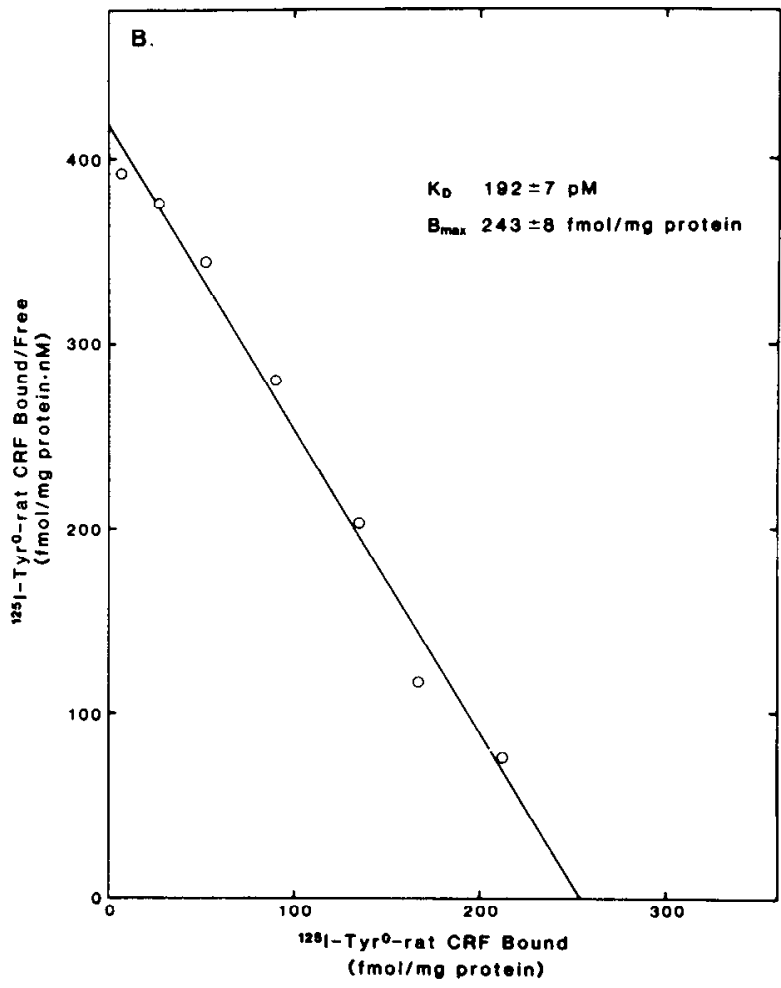

Figure 8. The binding of ${ }^{125 I-T y r^{0}}$ rat/human CRF to rat olfactory bulb membranes as a function of increasing ligand concentration. $A$, Direct plot of the data showing the total amount of ${ }^{125} \mathrm{I}-\mathrm{Tyr}^{\circ} \mathrm{rat} /$ human CRF bound, the amount of ${ }^{125} \mathrm{I}-\mathrm{Ty} \mathrm{r}^{\circ} \mathrm{rat} / \mathrm{human} \mathrm{CRF}$ bound in the presence of 1 $\mu \mathrm{M}$ rat CRF (blank), and specific (total minus blank) binding. $B$, Scatchard plot of ${ }^{125} \mathrm{I}$-Tyr ${ }^{\circ} \mathrm{rat} / \mathrm{human}$ CRF specific binding. Crude mitochondrial/ synaptosomal membrane preparations of rat olfactory bulb were incubated for $120 \mathrm{~min}$ at room temperature with increasing concentrations (0.05$1 \mathrm{nM}$ ) of ${ }^{125} \mathrm{I}-\mathrm{Tyr}^{0} \mathrm{rat} / \mathrm{human}$ CRF. The concentration of free ${ }^{125} \mathrm{I}-\mathrm{Tyr}^{0} \mathrm{rat}$ human CRF was measured directly in aliquots of the supernatant after the binding reaction was terminated by centrifugation. The data shown are from a representative experiment. Each value is the average of 3 determinations, which varied by less than $10 \%$. 


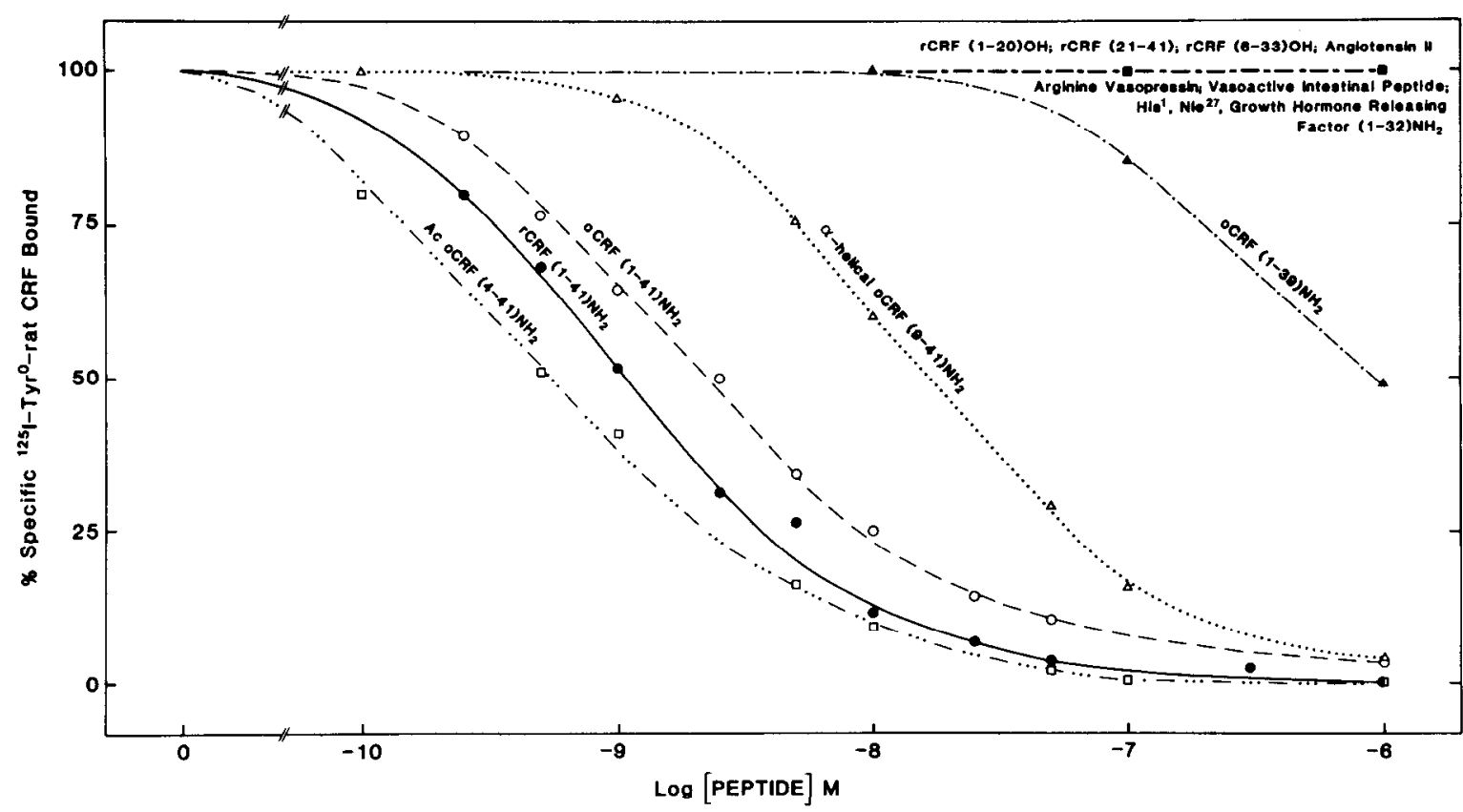

Figure 9. Characterization of the pharmacological specificity of ${ }^{125}{ }^{2}-\mathrm{Tyr}^{0} \mathrm{rat}^{\mathrm{h}}$ human CRF binding in rat olfactory bulb membranes. Crude mitochondrial/synaptosomal membranes were incubated for $120 \mathrm{~min}$ at room temperature in the presence of $0.1 \mathrm{nM}{ }^{125} \mathrm{I}-\mathrm{Tyr}^{\circ} \mathrm{rat} / \mathrm{human} \mathrm{CRF}$ and varying concentrations of CRF-related and unrelated peptides. Nonspecific binding was determined in the presence of $1 \mu \mathrm{M}$ rat CRF and was subtracted from the total binding. The data shown are from representative experiments. Each point represents the mean of a triplicate determination where the standard error is less than $10 \%$ of the mean. Shown are acetyl oCRF (4-41)NH $; r C R F(1-4) N H_{2} ; o C R F(1-4) N H_{2} ; \alpha-h e l i c a l o C R F(9-$ 4I) $\mathrm{NH}_{2} ; o C R F(1-39) \mathrm{NH}_{2}$ and one of several noncompeting $r C R F$ fragments or unrelated peptides.

was accomplished by a small (10\%) reduction in the $B_{\max }$ value. Conversely, the effect of magnesium on increased ${ }^{125} \mathrm{I}-\mathrm{rCR}$ binding was accomplished by decreasing both the $K_{\mathrm{d}}(50 \%$ decrease, from $1 \mathrm{mM}$ to $10 \mathrm{mM} \mathrm{MgCl}_{2}$ ) and the number of binding sites (Fig. 11). These results are consistent with the characteristic effects of adenylate cyclase modulators on agonist binding to receptors mediating their effects through cAMP production.

\section{Regional distribution of ${ }^{125}$ I-rCRF binding sites in rat $C N S$}

Equilibrium-binding parameters, determined from Scatchard plots of competition experiments using unlabeled rCRF and membranes prepared from different CNS regions, indicated generally uniform $K_{d}$ values but a heterogeneous distribution of ${ }^{125}$ I-rCRF binding sites across 11 rat CNS regions (Fig. 12). The

Table 2. Pharmacological specificity of ${ }^{125}$ I-Tyr ${ }^{0}$ rat/human CRF receptor binding to rat olfactory bulb membranes

\begin{tabular}{|c|c|c|c|c|}
\hline \multirow[b]{2}{*}{ Peptide } & \multicolumn{3}{|c|}{${ }^{125} \mathrm{I}-\mathrm{Tyr}^{0} \mathrm{rat} / \mathrm{human} \mathrm{CRF}$ binding data } & \multirow{2}{*}{$\begin{array}{l}\text { Bioassay } \\
\text { data: } \\
\text { intrinsic } \\
\text { activity }\end{array}$} \\
\hline & $K_{\mathrm{i}}(\mathrm{nM})$ & Hill coefficient & $\begin{array}{l}\text { Relative } \\
\text { potency }\end{array}$ & \\
\hline $\mathrm{rCRF}$ & $1.01 \pm 0.05(6)$ & $0.84 \pm 0.03$ & 1.0 & 1.0 \\
\hline oCRF & $2.39 \pm 0.11(4)$ & $0.66 \pm 0.06$ & 0.4 & 1.0 \\
\hline$\alpha$-helical oCRF (9-41) & $16.73 \pm 1.67(3)$ & $0.83 \pm 0.01$ & 0.06 & $<0.1$ \\
\hline Ac oCRF (4-41) & $0.47 \pm 0.08(3)$ & $0.86 \pm 0.04$ & 2.1 & 1.22 \\
\hline oCRF (1-39) & 828.2 & & 0.001 & $<0.01$ \\
\hline rCRF (1-20) & $>1000(3)$ & & $<0.001$ & $<0.01$ \\
\hline rCRF (21-41) & $>1000(3)$ & & $<0.001$ & $<0.01$ \\
\hline rCRF (6-33) & $>1000(3)$ & & $<0.001$ & $<0.01$ \\
\hline Angiotensin II & $>1000(3)$ & & $<0.001$ & \\
\hline AVP & $>1000(3)$ & & $<0.001$ & \\
\hline VIP & $>1000(3)$ & & $<0.001$ & \\
\hline $\mathrm{His}^{1}, \mathrm{Nle}^{27} \mathrm{GRF}$ & $>1000(3)$ & & $<0.001$ & \\
\hline
\end{tabular}

Peptides at 3-12 concentrations competed with 30-50 pM ${ }^{125}$ I-Tyr ${ }^{\circ}$ rat/human CRF during a 120 min incubation at room temperature. All assays were conducted in triplicate for the number of experiments in parentheses, and the $K_{i}$ (inhibitory binding-affinity constant) and Hill coefficient (mean \pm SEM) values were obtained from competition curve data analyzed by the computer program EBDA (McPherson, 1983), which provided initial estimates of the equilibriumbinding parameters. The bioassay data were obtained from previous studies by Rivier et al. $(1982,1983,1984)$. rCRF, Rat corticotropin-releasing factor; $O C R F$, ovine corticotropin-releasing factor; AVP, arginine vasopressin; VIP, vasoactive intestinal peptide; GRF, growth hormone-releasing factor. 


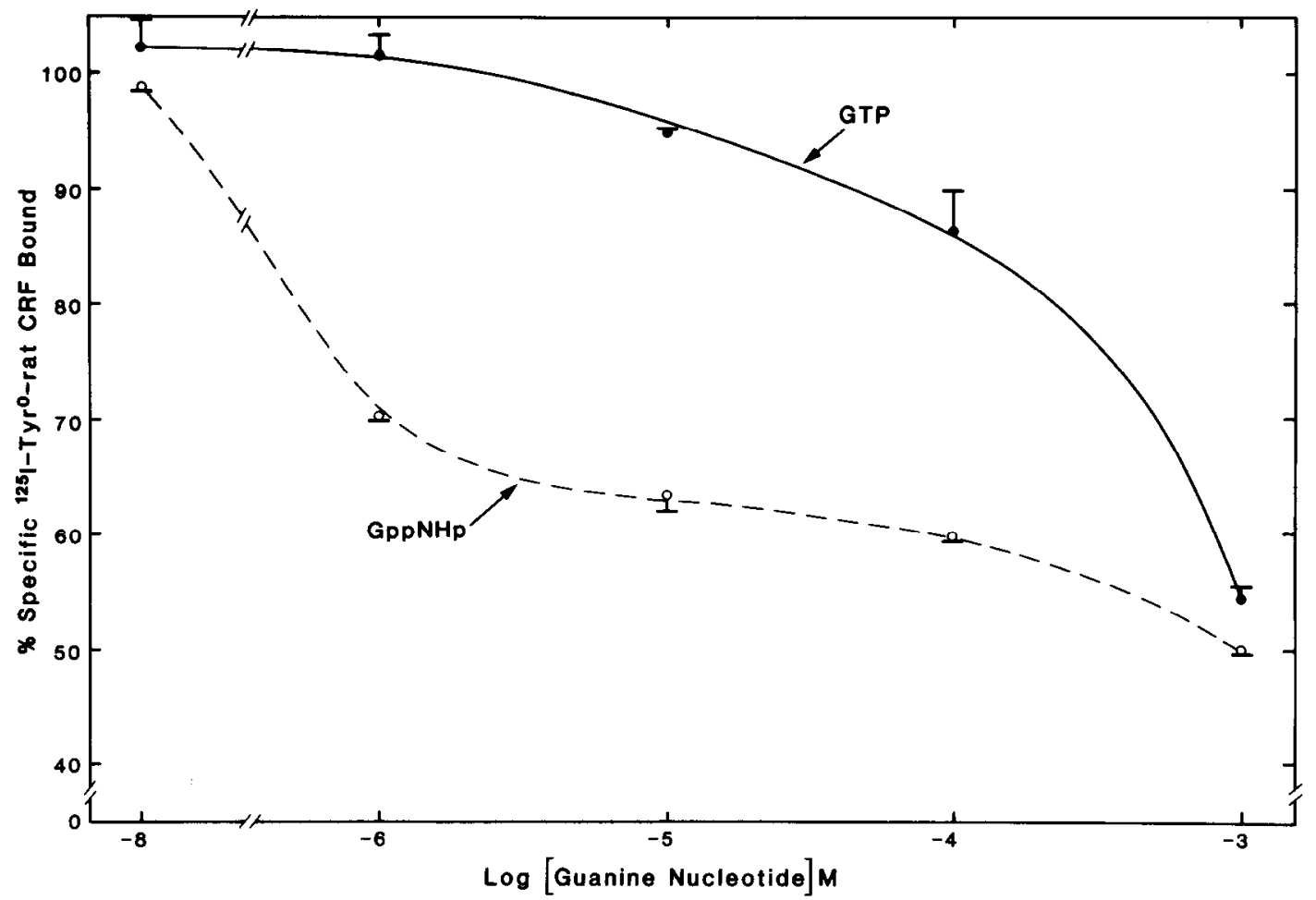

Figure 10. Effects of guanine nucleotides on the binding of ${ }^{125} \mathrm{I}-\mathrm{Tyr}^{0}$ rat/human CRF to rat olfactory bulb membranes. Crude mitochondrial/ synaptosomal membrane preparations of olfactory bulb were incubated for $2 \mathrm{hr}$ at room temperature in the presence of $0.1 \mathrm{~nm}{ }^{125 \mathrm{I}-T y r^{0} \mathrm{rat} / \mathrm{human}}$ $\mathrm{CRF}$ and the indicated concentrations of guanosine-5'-triphosphate $(G T P)$ or 5'-guanylimidodiphosphate $(G p p N H p)$. Nonspecific binding was determined in the presence of $1 \mu \mathrm{M}$ rat CRF. The data are based on quadruplicate determinations; mcan \pm SEM.

highest density of binding sites in the rat CNS was in the olfactory bulb. The density of anterior pituitary binding sites (approximately 2.5 times that of olfactory bulb) is included to indicate the relative abundance of brain binding sites in comparison with this tissue, more commonly employed in CRF binding and bioassays. High levels of ${ }^{125} \mathrm{I}-\mathrm{rCRF}$ binding sites were detected in olfactory bulb, cerebellum, cortex, and striatum. Progressively lower but significant receptor densities were observed in cervical spinal cord, hypothalamus, medulla, midbrain, thalamus, pons, and hippocampus.

\section{Discussion}

In the present study, we have examined the influence of various incubation parameters on ${ }^{125} \mathrm{I}-\mathrm{rCRF}$ binding in rat olfactory bulb membranes. ${ }^{125} \mathrm{I}-\mathrm{rCR} F$ binding was dependent on time and temperature, was sensitive to the $\mathrm{pH}$, ionic strength, and cationic composition of the incubation buffer, and was linear with membrane protein concentration. Receptor binding was optimal in 50 mm Tris- $\mathrm{HCl}$ buffer, $\mathrm{pH} 7.2$, and was maximal at room temperature for 90-180 min, with minimal degradation of the radioiodinated peptide occurring under these conditions. The binding of ${ }^{125} \mathrm{I}-\mathrm{rCRF}$ was saturable, reversible, and of high affinity $\left(K_{\mathrm{d}}\right.$ of $\left.190 \mathrm{pM}\right)$. ${ }^{125}$ I-rCRF binding sites were localized primarily to a tissue preparation that was rich in synaptic membranes. The binding sites for ${ }^{125} \mathrm{I}-\mathrm{rCRF}$ in rat olfactory bulb membrane preparations exhibit a pharmacological specificity for CRF analogs and fragments that correlates extremely well with their relative intrinsic potency in stimulating or inhibiting anterior pituitary secretion of ACTH in vitro (see Table 2). The specificity of the ${ }^{125} \mathrm{I}$-rCRF binding site is further strengthened by the lack of inhibitory activity of peptides such as angiotensin
II, arginine vasopressin, and vasoactive intestinal peptide, all of which have been shown to also stimulate ACTH secretion through their own respective receptors (Vale and Rivier, 1977; Steele et al., 1981; Westendorf et al., 1983). The kinetic and pharmacological characteristics of the ${ }^{125}$ I-rCRF binding sites in rat olfactory bulb were comparable to the characteristics found in the other brain regions examined and are similar to those previously observed in rat (Wynn et al., 1983; De Souza et al., 1984a; Holmes et al., 1984), bovine (De Souza et al., 1984a; De Souza and Kuhar, 1986a, b) and human (De Souza et al., 1985c) pituitary and in rat (De Souza et al., 1984b, 1985a, b; Wynn et al., 1984; Chen and Bilezikjian, 1985; Dc Souza and Kuhar, 1986a, b) and human (De Souza et al., 1986) brain using a variey of ligands. These data substantiate earlier suggestions (Peterfreund and Vale, 1983; Valentino et al., 1983; Britton et al., 1984) that some structural requirements for CRF activity are shared by brain and pituitary receptors.

Monovalent cations had no effect on ${ }^{125}$ I-rCRF binding over the range of concentrations examined, whereas divalent cations such as $\mathrm{CaCl}_{2}$ and $\mathrm{MgCl}_{2}$ increased binding affinity. The effects of $\mathrm{MgCl}_{2}$ on the binding of ${ }^{125} \mathrm{I}-\mathrm{rCRF}$ are consistent with previous data demonstrating the ability of magnesium ions to enhance agonist binding to receptors coupled to adenylate cyclase (DeLean et al., 1980). Likewise, the ability of guanine nucleotides to inhibit ${ }^{125}$ I-rCRF binding is consistent with the hypothesis that receptors for CRF are coupled to adenylate cyclase. There are recent studies reporting the ability of CRF to stimulate adenylate cyclase activity in some brain areas (Wynn et al., 1984; Chen and Bilezikjian, 1985); however, there are brain regions with abundant CRF receptors that lack CRF-stimulated adenylate cyclase activity (Chen and Bilezikjian, 1985). These data 


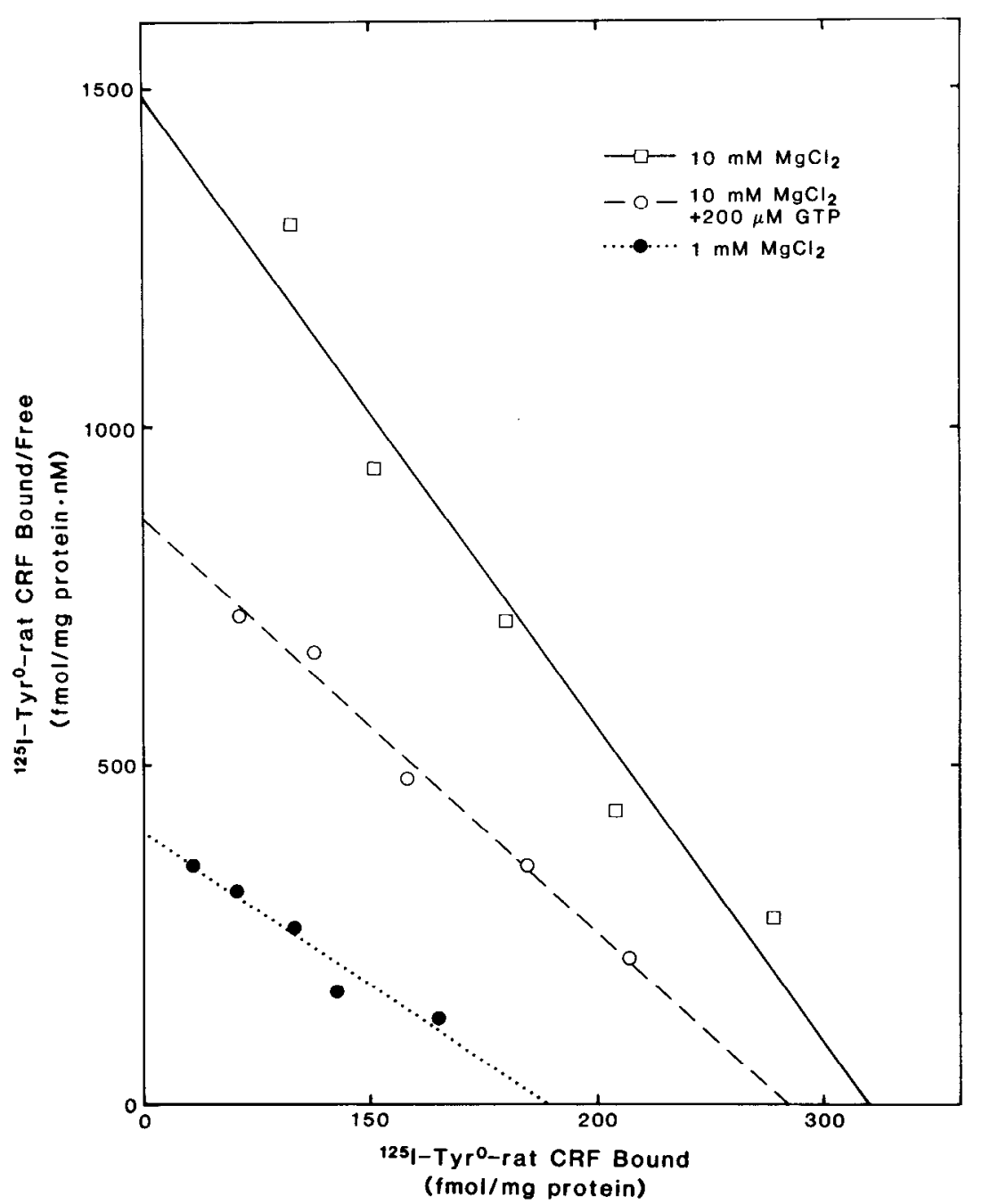

Figure 11. Effects of magnesium ions and guanosine-5'-triphosphate (GTP) on the binding of ${ }^{125} \mathrm{I}-\mathrm{Tyr}^{0} \mathrm{rat} / \mathrm{human}$ CRF to rat olfactory bulb membranes. Scatchard plots of the ${ }^{125} \mathrm{I}-\mathrm{Tyr}^{0} \mathrm{rat} / \mathrm{hu}-$ man CRF binding to crude mitochondrial/synaptosomal membranes in the presence of $1 \mathrm{mM} \mathrm{MgCl}, 10 \mathrm{mM} \mathrm{MgCl}_{2}$, or $10 \mathrm{mM} \mathrm{MgCl}_{2}$ plus $200 \mu \mathrm{M} \mathrm{GTP}$ and increasing concentrations of ligand (0.05-1 nM). Incubations were for 120 min at room temperature. Nonspecific binding was in the presence of $1 \mu \mathrm{M}$ rat CRF. The concentration of free ${ }^{125} \mathrm{I}-\mathrm{Tyy}^{0}$ rat/human CRF was measured directly in aliquots of the supernatant after the binding reaction was terminated by centrifugation. Points are the means of triplicate determinations in a representative experiment. imply that CRF-induced signal transduction may be mediated by additional second messengers or by inhibition of adenylate cyclase, as reported for other systems. For example, cholinergic muscarinic agonists have been shown to inhibit cAMP formation as well as to stimulate phosphoinositide metabolism (Brown and Brown, 1984), while dopaminergic agonists have been shown to mediate both the stimulation and inhibition of adenylate cyclase activity through distinct dopaminergic receptor subtypes (Kebabian and Calne, 1979; Creese et al., 1983). Recently, guanine nucleotides have been shown to also reduce binding of agonists to receptors that mediate their effects through phosphoinositide metabolism (Cockcroft and Gomperts, 1985). Thus, sensitivity of ${ }^{125}$ I-rCRF binding to guanine nucleotides does not preclude the possibility that CRF receptors may also be coupled to phosphoinositide metabolism. Given suggestions that there might be more than 1 class of binding site for CRF in brain in this and other reports (Chen and Bilezikjian, 1985; De Souza et al., 1985a; De Souza and Kuhar, 1986a), it would be of interest to examine in greater detail the roles of other transduction mechanisms, in addition to CRF-stimulated adenylate cyclase, in mediating the actions of CRF; such studies are currently under way in our laboratory.

The results of the present study confirm the presence and heterogeneous distribution of specific, high-affinity receptors for CRF throughout the rat CNS. The highest densities of ${ }^{125}$ I-rCRF binding sites were detcted in olfactory bulb, cerebellum, cerebral cortex, and striatum, with progressively lower but significant receptor densities present in spinal cord, hypothalamus, medulla, midbrain, thalamus, pons, and hippocampus. In general, the distribution of CRF binding sites at the gross level of these homogenate binding assays correlates well with previous data from higher-resolution autoradiographic localization studies (De Souza et al., 1984b, 1985a, b; Wynn et al., 1984; De Souza and Kuhar, 1986a, b). Centrally administered CRF produces a broad spectrum of autonomic and behavioral effects, including increases in plasma levels of catecholamines (Brown et al., 1982) and glucose (Brown et al., 1982), increases in cardiovascular parameters, including heart rate and mean arterial pressure (Fisher et al., 1983), altered gastric acid secretion (Tache et al., 1983), and a variety of behavioral changes associated with general arousal, such as increased locomotor activity in familiar surroundings (Britton et al., 1982, 1984; Sutton et al., 1982; Veldhuis and De Wied, 1984), increased "emotionality" in a novel environment (Britton et al., 1982, 1984; Sutton et al,. 1982; Veldhuis and De Wied, 1984), and decreases in feeding (Morley and Levine, 1982) and sexual (Sirinathsinghji et al., 1983) behaviors. In addition, numerous areas of the brain, including the cortex, hypothalamus, thalamus, and lateral septal area have been shown to be electrophysiologically responsive to iontophoretic application of CRF (Eberly et al., 1983), as 


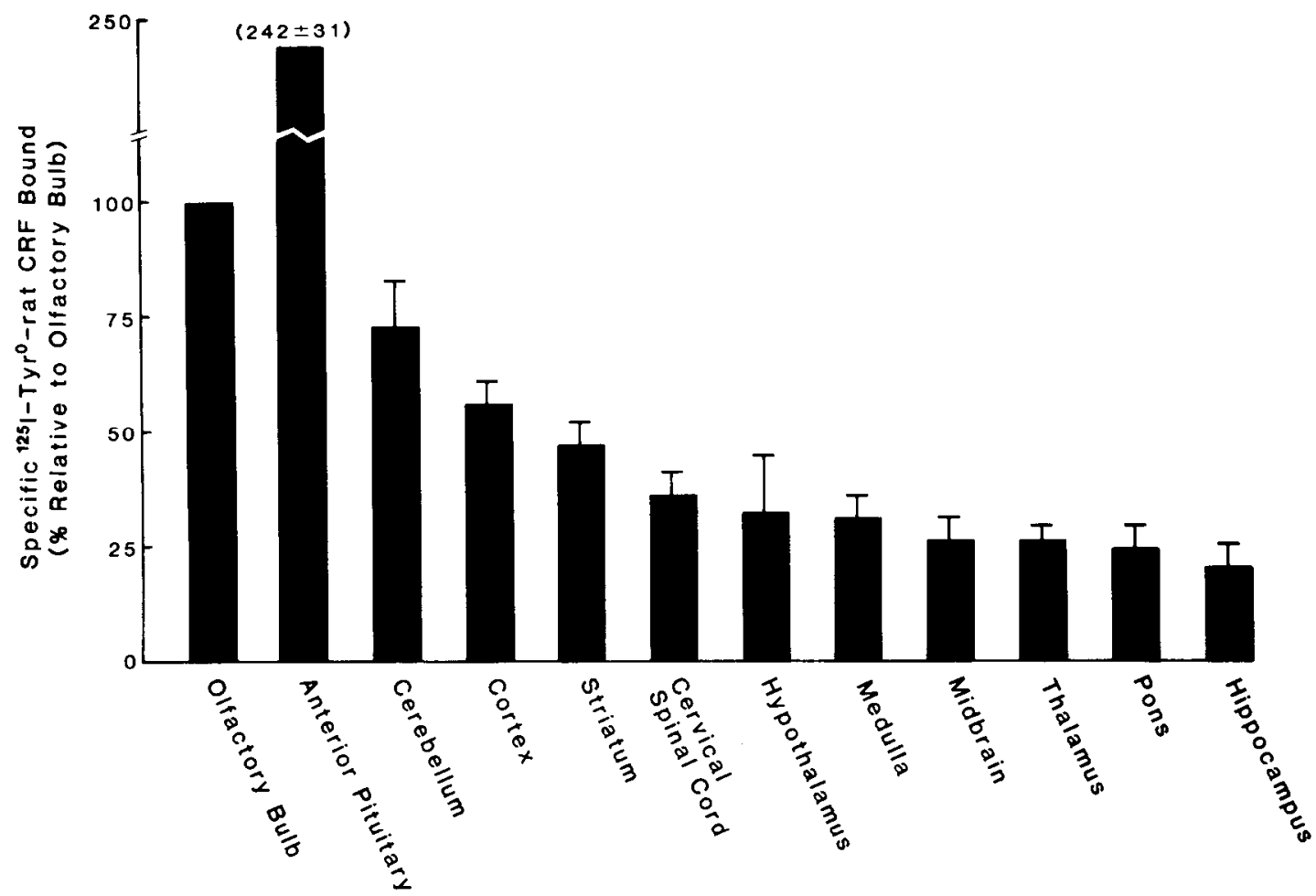

Figure 12. Regional distribution of binding sites for ${ }^{125} \mathrm{I}-\mathrm{Tyy}^{0}$ rat/human CRF in the rat CNS and anterior pituitary. Crude mitochondrial/ synaptosomal membrane preparations from each of the indicated regions were incubated for $2 \mathrm{hr}$ at room temperature in the presence of $0.1 \mathrm{nM}$ ${ }^{125} \mathrm{I}-\mathrm{Tyr}^{\circ}{ }^{\mathrm{rat}} / \mathrm{human} \mathrm{CRF}$ and incrcasing concentrations of unlabeled rat CRF. The values for each region were determined using the data analysis described in Materials and Methods and are presented here as a percentage of the level of binding observed in rat olfactory bulb membranes. Relative values represent the mean \pm SEM determined from results of 3-5 experiments comparing the levels of ${ }^{125}$ I-Tyr ${ }^{0}$ rat/human CRF binding in the absence (total) and presence (blank) of $1 \mu \mathrm{M}$ rat CRF across all regions and 3-5 experiments in which regional competition curves using increasing concentrations of unlabeled rat CRF were analyzed by EBDA to obtain $B_{\max }$ values.

have discrete brain stem areas, much as the locus coeruleus and parabrachial nucleus (Valentino et al., 1983). Hippocampal slice preparations have been employed to demonstrate the electrophysiological effects of CRF in vitro (Aldenhoff et al., 1983), and intracerebroventricular administration of high doses of CRF has been shown to elicit epileptiform seizures that appear, on the basis of associated electroencephalographic patterns, to originate in the amygdala (Ehlers et al., 1983). It is likely that the diversity of physiological and behavioral responses to CRF, in conjunction with the variety of areas that are electrophysiologically responsive to this peptide, would demand a correspondingly broad anatomical distribution of receptors for CRF in the CNS.

In contrast to the good correlation between regional levels of binding sites for ${ }^{125} \mathrm{I}$-rCRF in these homogenate binding assays, and the localization of CRF receptors by light-microscopic autoradiography, there are areas in the rat CNS in which the presence of high concentrations of CRF receptors does not correspond to the reported distribution of CRF-immunoreactive (CRF-IR) fibers. Primary examples of this disparity involve the olfactory bulb and cerebellum. In the rat cerebellum, moderate (Cummings et al., 1983), low (Olschowka et al., 1982), and undetectable (Swanson et al., 1983) densities of CRF-IR fibers have been reported, while the second highest concentration of ${ }^{125}$ I-rCRF binding sites in the CNS was detected in this brain region. Similarly, the olfactory bulb has the highest concentration of CRF receptors in the CNS, but only low concentrations of olfactory bulb CRF-IR have been reported (Swanson et al.,
1983). Similar mismatches between the levels of transmitter and receptor have been noted in previous studies involving both classical neurotransmitters (Palacios and Kuhar, 1980; Palacios et al., 1980) and neuropeptides (Zarbin et al., 1983; Goedert et al., 1984; Mantyh et al., 1984), and the "mismatch problem" has been the topic of a recent report (Kuhar, 1985). The problem, as it relates to CRF in brain, has been discussed in detail in a recent paper (De Souza et al., 1985a).

The high density of CRF receptors in the rat olfactory bulb and their distribution throughout the olfactory system are striking. CRF receptors in the rat olfactory bulb have been localized autoradiographically to discrete laminar divisions associated with the termination of primary olfactory afferents and with the origin of olfactory efferent axons (Wynn et al., 1984; De Souza et al., 1985a; De Souza and Kuhar, 1986b). There is evidence in the literature suggesting that sexual, reproductive, social, and feeding behaviors of most mammalian species are mediated by olfactory substances and pheromonal agents acting through the olfactory system (see Whitten and Bronson, 1970). CRF influences both feeding behavior and sexual activity. Although the hypothalamus is the primary anatomical locus regulating sexual activity and feeding behavior, hypothalamic neuronal activity can be modulated by olfactory impulses relayed through the circuit involving the olfactory bulb, pyriform cortex, amygdala, and subiculum; moderate to high densities of CRF are present throughout the circuit (De Souza et al., 1985a). In rats, olfactory bulbectomy serves as a good model for the study of many of the manifestations seen in clinical depression (Leonard and Tuite, 
1981); altered CRF concentrations in the CSF (Nemeroff et al., 1984) and adrenocorticotropic hormone response to CRF (Gold et al., 1984) have been reported in depressed patients. Thus, while the role of CRF in olfactory-mediated behaviors is, at present, unknown, the presence of high concentrations of receptors throughout the olfactory system may suggest a functional role for CRF in mediating these influences.

In the rat neocortex, CRF cell bodies are concentrated in laminae II and III, with projections to laminae I and IV (Olschowka et al., 1982; Cummings et al., 1983; Swanson et al., 1983), areas rich in CRF receptors (De Souza et al., 1984b, 1985a, b; Wynn et al., 1984; De Souza and Kuhar, 1986a, b). The biological relevance of CRF receptors in the cerebral cortex is supported by the observation that CRF stimulates secretion of somatostatin from dispersed rat cerebral cortical cells (Peterfreund and Vale, 1983). Very recently, we found that in Alzheimer's disease the concentrations of CRF-IR were reduced and there were reciprocal increases in the number of ${ }^{125}$ I-rCRF binding sites in affected areas of the cerebral cortex (De Souza et al., 1986). These data from human cortex (De Souza et al., 1986) suggest a functional role for CRF in normal cortical function and possibly in the pathophysiology of the dementia occurring in Alzheimer's disease.

The hypothalamus is a primary brain region involved in the regulation of pituitary function. High concentrations of CRFIR are found in cell bodies in the paraventricular nucleus (PVN) of the hypothalamus and in the median eminence where the neurons originating in the PVN terminate (Olschowka et al., 1982; Cummings et al., 1983; Swanson ct al., 1983). Although low to moderate concentrations of ${ }^{125}$ I-rCRF binding sites are found in homogenates of whole hypothalamus, previous autoradiographic data have localized CRF receptors at moderate to high concentrations in the PVN and median eminence, respectively (De Souza et al., 1984, 1985a, b; De Souza and Kuhar, $1986 \mathrm{a}, \mathrm{b})$. The CRF binding sites in these hypothalamic areas may represent presynaptic autoreceptors or receptors for interneuronal communication that may play important roles in regulating peptide release. The hypothalamus may also be a primary site of action for integrating the endocrine, autonomic and behavioral effects of CRF. Microinfusions of CRF into the hypothalamus suppress sexual behavior (Sirinathsinghji et al., 1983). In addition, intracerebroventricular injections of CRF have been shown to inhibit the release of growth hormone (Ono et al., 1984; Rivier and Vale, 1984b), luteinizing hormone (Ono ct al., 1984; Rivier and Vale, 1984b), vasopressin, and oxytocin (Plotsky et al., 1985) and to have deleterious effects on reproductive functions (Rivier and Vale, 1984a). CRF can also stimulate the secretion of somatostatin by cultured rat hypothalamic cells (Peterfreund and Vale, 1983).

In summary, we have used an iodine-125-labeled analog of the endogenous ligand to identify, characterize, and localize receptors for CRF in discrete areas of the rat CNS. The effects of guanine nucleotides in decreasing and of magnesium ions in increasing ${ }^{125} \mathrm{I}$-rCRF binding are consistent wth data demonstrating that some populations of CRF receptors are coupled to adenylate cyclase; however, whether there are additional CRFmediated signal transduction mechanisms remains to be determined. These data provide further support for the proposed role of CRF as a neurotransmitter in the CNS. This study demonstrating the characteristics of CRF receptors in brain provides a means for better understanding the various functions of this neuropeptide under physiological and pathological conditions.

\section{References}

Aldenhoff, J. B., D. L. Gruol, J. Rivier, W. Vale, and G. R. Siggins (1983) Corticotropin-releasing factor decreases post-burst hyperpolarizations and excites hippocampal pyramidal neurons in vitro. Science $221: 875-876$.

Britton, D. R., G. F. Koob, J. Rivier, and W. Vale (1982) Intraventricular corticotropin-releasing factor enhances behavioral effects of novelty. Life Sci. 31: 363-367.

Britton, D. R., D. K. Hoffman, K. Lederis, and J. Rivier (1984) A comparison of the behavioral effects of CRF, sauvagine and urotensin I. Brain Res. 304: 201-205.

Brown, J. H., and S. L. Brown (1984) Agonists differentiate muscarinic receptors that stimulate cyclic AMP formation from those that stimulate phophoinositide metabolism. J. Biol. Chem. 259: 3777-3781.

Brown, M. R., L. A. Fisher, J. Spiess, C. Rivier, J. Rivier, and W. Vale (1982) Corticotropin-releasing factor: Actions on the sympathetic nervous system and oxygen consumption. Life Sci. 30: 207-210.

Chen, F. M., and L. M. Bilezikjian (1985) CRF stimulates adenylate cyclase in rat brain. In The 67 th Annual Meeting of the Endocrine Society, p. 999.

Cockcroft, S., and B. D. Gomperts (1985) Role of guanine nucleotide binding protein in the activation of polyphosphoinositide phosphodiesterase. Nature 314: 534-536.

Creese, I., D. R. Sibley, M. W. Hamblin, and S. E. Leff (1983) The classification of dopamine receptors: Relationship to radioligand binding. Annu. Rev. Neurosci. 6: 43-71.

Cummings, S., R. Elde, J. Ells, and A. Lindall (1983) Corticotropinreleasing factor immunoreactivity is widely distributed within the central nervous system of the rat: An immunohistochemical study. J. Neurosci. 3: 1355-1368.

DeLean, A., J. M. Stadel, and R. J. Lefkowitz (1980) A ternary complex model explains the agonist-specific binding properties of the adenylate cyclase-coupled $\beta$-adrenergic receptor. J. Biol. Chem. 255: 7108-7117.

De Souza, E. B. (1985) Corticotropin-releasing factor. Comp. Ther. II: 3-5.

De Souza, E. B., and M. J. Kuhar (1986a) Corticotropin-releasing factor receptors in the pituitary gland and central nervous system: Methods and overview. Methods Enzymol. 124: 560-590.

De Souza, E. B., and M. J. Kuhar (1986b) Corticotropin-releasing factor receptors: Autoradiographic identification. In Neuropeptides in Neurologic and Psychiatric Disease, J. B. Martin and J. Barchas, eds., pp. 179-198, Raven, New York.

De Souza, E. B., M. H. Perrin, J. E. Rivier, W. W. Vale, and M. J. Kuhar (1984a) Corticotropin-releasing factor receptors in rat pituitary gland: Autoradiographic localization. Brain Res. 296: 202-207.

De Souza, E. B., M. H. Perrin, T. R. Insel, J. Rivier, W. W. Vale, and M. J. Kuhar (1984b) Corticotropin-releasing factor receptors in rat forebrain: Autoradiographic identification. Science 224: 1449-1451.

De Souza, E. B., T. R. Insel, M. H. Perrin, J. Rivier, W. W. Vale, and M. J. Kuhar (1985a) Corticotropin-releasing factor receptors are widely distributed within the rat central nervous system: An autoradiographic study. J. Neurosci. 5: 3189-3203.

De Souza, E. B., T. R. Insel, M. H. Perrin, J. Rivier, W. W. Vale, and M. I. Kuhar (1985b) Differential regulation of corticotropin-releasing factor receptors in anterior and intermediate lobes of pituitary and in brain following adrenalectomy in rats. Neurosci. Lett. 56: 121128.

De Souza, E. B., M. H. Perrin, P. J. Whitehouse, J. E. Rivier, W. W. Vale, and M. J. Kuhar (1985c) Corticotropin-releasing factor receptors in human pituitary gland: Autoradiographic localization. Neuroendocrinology 40: 419-422.

De Souza, E. B., P. J. Whitehouse, M. J. Kuhar, D. L. Price, and W. W. Vale (1986) Reciprocal changes in corticotropin-releasing factor (CRF)-like immunoreactivity and CRF receptors in cerebral cortex of Alzheimer's disease. Nature 319: 593-595.

Eberly, L. B., C. A. Dudley, and R. L. Moss (1983) Iontophoretic mapping of corticotropin-releasing factor (CRF) sensitive neurons in the rat forebrain. Peptides 4: 837-841.

Ehlers, C. L., S. J. Henriksen, M. Wang, J. Rivier, W. W. Vale, and F. E. Bloom (1983) Corticotropin-releasing factor produces increases in brain excitability and convulsive seizures in rats. Brain Res. 278: 332-336.

Fisher, L. A., G. Jessen, and M. R. Brown (1983) Corticotropinreleasing factor (CRF): Mechanism to evaluate mean arterial pressure and heart rate. Reg. Pept. 5: 153-161. 
Glowinski, J., and L. L. Iversen (1966) Regional studies of catecholamines in the rat brain. I. The disposition of ${ }^{3} \mathrm{H}$-norepinephrine, ${ }^{3} \mathrm{H}$ dopamine and ${ }^{3} \mathrm{H}-D O P A$ in various regions of the brain. J. Neurochem. 13: 665-669.

Goedert, M., P. W. Mantyh, P. C. Emson, and S. Hunt (1984) Inverse relationship between neurotensin receptors and neurotensin-like immunorcactivity in the cat striatum. Nature 307: 543-546.

Gold, P. W., G. Chrousos, C. Kellner, R. Post, A. Roy, P. Augerinos, H. Schulte, E. Oldfield, and D. L. Loriaux (1984) Psychiatric implications of basic and clinical studies with corticotropin-releasing factor. Am. J. Psychiatry 141: 619-627.

Holmes, M. C., F. A. Antoni, and T. Szeintendnei (1984) Pituitary receptors for corticotropin-releasing factor: No effect of vasopressin on binding or activation of adenylate cyclase. Neuroendocrinology 39: 1001-1007.

Kebabian, J. W., and D. B. Calne (1979) Multiple receptors for dopamine. Nature 227: 93-96.

Kuhar, M. J. (1985) The mismatch problem in receptor mapping studies. Trends Neurosci. 8: 190-191.

Leonard, B. E., and M. Tuite (1981) Anatomical, physiological, and behavioral aspects of olfactory bulbectomy in the rat. Int. Rev. Neurobiol. 22: 251-286.

Lowry, O. H., N. J. Rosebrough, A. L. Farr, and R. J. Randall (1951) Protein measurement with the Folin phenol reagent. J. Biol. Chem. 193: 265-275.

Mantyh, P. W., S. P. Hunt, and J. E. Maggio (1984) Substance P receptors: Localization by light microscopic autoradiography in rat brain using $\left[{ }^{3} \mathrm{H}\right] \mathrm{SP}$ as the radioligand. Brain Res. 307: 147-165.

McPherson, G. A. (1983) A practical computer-based approach to the analysis of radioligand binding experiments. Comput. Programs Biomed. 17: 107-114.

Morley, J. F., and A. S. Levine (1982) Corticotropin-releasing factor, grooming and ingestive behavior. Life Sci. 31: 1459-1464.

Munson, P. J., and D. Rodbard (1980) LIGAND: A versatile computerized approach for characterization of ligand-binding systems. Anal. Biochem. 297: 220-229.

Nemeroff, C. B., E. Widerlov, G. Bissette, H. Walleus, I. Karlsson, K Eklund, C. D. Kilts, P. T. Loosen, and W. Vale (1984) Elevated concentrations of CSF corticotropin-releasing factor-like immunoreactivity in depressed patients. Science 226: 1342-1344.

Olschowka, J. A., T. L. O'Donohue, G. P. Mueller, and D. M. Jacobowitz (1982) The distribution of corticotropin-releasing factor-like immunoreactive neurons in rat brain. Peptides 3: 995-1015.

Ono, N., M. D. Lumpkin, W. K. Samson, J. K. McDonald, and S. M. McCann (1984) Intrahypothalamic action of corticotropin-releasing factor (CRF) to inhibit growth hormone and $\mathrm{LH}$ release in the rat. Life Sci. 35: 1117-1123.

Palacios, J. M., and M. J. Kuhar (1980) Beta-adrenergic receptor localization by light microscopic autoradiography. Science $208: 1378$ 1380.

Palacios, J. M., W. S. Young, III, and M. J. Kuhar (1980) Autoradiographic localization of gamma-aminobutyric acid (GABA) receptors in rat cerebellum. Proc. Natl. Acad. Sci. USA 77: 670-674.

Peterfreund, R. A., and W. V. Vale (1983) Ovine corticotropin-releasing factor stimulates somatostatin secretion from cultured brain cells. Endocrinology 112: 1275-1278.

Plotsky, P. M., T. O. Bruhn, and S. Otto (1985) Central modulation of immunoreactive arginine vasopressin and oxytocin secretion into the hypophysial-portal circulation by corticotropin-releasing factor. Endocrinology 116: 1669-1671.

Rivier, C., and W. Vale (1984a) Influence of corticotropin-releasing factor on reproductive functions in the rat. Endocrinology 114:914 921.

Rivier, C. R., and W. Vale (1984b) Corticotropin-releasing factor (CRF) acts centrally to inhibit growth hormone secretion in the rat. Endocrinology 114: 2409-2411.

Rivier, J., J. Spiess, C. Rivier, R. Galyean, and W. W. Vale (1982) Solid phase synthesis of amunine (CRF), sauvagine and urotensin I. In Peptides, K. Blaha and P. Malon, eds., pp. 597-602, Wide Gruyter, Berlin.
Rivier, J., J. Spiess, and W. Vale (1983) Characterization of rat hypothalamic corticotropin-releasing factor. Proc. Natl. Acad. Sci. USA $80: 4851-4855$.

Rivier, J., C. Rivier, and W. Vale (1984) Synthetic competitive antagonists of corticotropin releasing factor: Effect on ACTH secretion in the rat. Science 224: 889-891.

Shibihara, S., Y. Morimoto, Y. Furutani, M. Notake, H. Takahashi, S. Shimizu, S. Horikawa, and S. Numa (1983) Isolation and sequence analysis of the human corticotropin-releasing factor precursor gene. EMBO J. 2: 775-779.

Sirinathsinghji, D. J. S., L. H. Rees, J. Rivier, and W. W. Vale (1983) Corticotropin-releasing factor is a potent inhibitor of sexual receptivity in the female rat. Nature 305: 232-235.

Smith, M., G. Bisette, T. A. Slotkin, D. L. Knight, and C. B. Nemeroff (1986) Release of corticotropin-releasing factor from rat brain regions in vitro. Endocrinology 118: 1997-2001.

Steele, M. K., A. Negro-Vilar, and S. W. McCann (1981) Effect of angiotensin II on in vivo and in vitro release of anterior pituitary hormones in the female rat. Endocrinology 109: 893-899.

Sutton, R. E., G. F. Koob, M. LeMoal, J. Rivier, and W. W. Vale (1982) Corticotropin-releasing factor produces behavioral activation in rats. Nature 297: 331-333.

Swanson, L. W., P. E. Sawchenko, J. Rivier, and W. W. Vale (1983) Organization of ovine corticotropin-releasing factor immunoreactive cells and fibers in the rat brain: An immunohistochemical study. Neuroendocrinology 36 : 165-186.

Tache, Y., Y. Goto, M. W. Gunion, W. W. Vale, J. Rivier, and M. Brown (1983) Inhibition of gastric acid secretion in rats by intracerebral injection of corticotropin-releasing factor. Science 222: 935937.

Vale, W., and C. Rivier (1977) Substances modulating the secretion of ACTH by cultured anterior pituitary cells. Fed. Proc. 36: 2094 2099.

Vale, W., J. Spiess, C. Rivier, and J. Rivier (1981) Characterization of a 41-residue ovine hypothalamic peptide that stimulates secretion of corticotropin and beta-endorphin. Science 213: 1394-1397.

Vale, W., C. Rivier, M. R. Brown, J. Spiess, G. Koob, L. Swanson, L. Bilezikjian, F. Bloom, and J. Rivier (1983) Chemical and biological characterization of corticotropin-releasing factor. Recent Prog. Horm. Res. 39: 245-270.

Valentino, R. J., S. L. Foote, and G. Aston-Jones (1983) Corticotropinreleasing factor activates noradrenergic neurons of the locus ceruleus. Brain Res. 270: 363-367.

Veldhuis, H. D., and D. De Wied (1984) Differential behavioral actions of corticotropin-releasing factor (CRF). Pharmacol. Biochem. Behav. 21: 707-713.

Westendorf, J. M., M. A. Philips, and A. Schonrunn (1983) Vasoactive intestinal peptide stimulates hormone release from corticotropic cells in culture. Endocrinology 112: 550-557.

Whittaker, V. P., and L. A. Barker (1972) The subcellular fractionation of brain tissue with special reference to the preparation of synaptosomes and their component organelles. In Methods of Neurochemistry, R. Fried, ed., pp. 1-52, Dekker, New York.

Whitten, W. K., and H. Bronson (1970) The role of pheromones in mammalian reproduction. In Communication by Chemical Signals, vol. 1, J. W. Johnston, Jr., D. G. Moulton, and A. Turk, eds., pp. 309-326, Appleton-Century-Crofts, New York.

Wynn, P. C., G. Aguilera, J. Morell, and K. J. Catt (1983) Properties and regulation of high-affinity pituitary receptors for corticotropinreleasing factor. Biochem. Biophys. Res. Commun. 110: 602-608.

Wynn, P. C., R. L. Hauger, M. C. Holmes, M. A. Millan, K. J. Catt, and G. Aguilera (1984) Brain and pituitary receptors for corticotropin releasing factor: Localization and differential regulation after adrenalectomy. Peptides 5: 1077-1084.

Zarbin, M. A., R. B. Innis, J. K. Wamsley, S. H. Snyder, and M. J. Kuhar (1983) Autoradiographic localization of cholecystokinin receptors in rodent brain. J. Neurosci. 3: 877-906. 